\title{
Urban Sub-Center Design Framework Based on the Walkability Evaluation Method: Taking Coomera Town Sub-Center as an Example
}

\author{
Jizhong Shao ${ }^{1,2, *} \mathbb{C}$, Minge Yang ${ }^{1}$, Guan Liu ${ }^{1}, \mathrm{Ye} \mathrm{Li}^{1}$, Dan Luo ${ }^{1}$, Yanran Tan ${ }^{1}$, Yuxin Zhang ${ }^{1}$ and Qize Song ${ }^{2}$ \\ 1 Landscape Architecture Department, Huazhong Agricultural University, Wuhan 430070, China; \\ yang17324@webmail.hzau.edu.cn (M.Y.); liug9535@nwafu.edu.cn (G.L.); waiittu@webmail.hzau.edu.cn (Y.L.); \\ luodan53@hotmail.com (D.L.); Rakkie211211@hotmail.com (Y.T.); 2016305201026@webmail.hzau.edu.cn (Y.Z.) \\ 2 School of Architecture, Nanjing Tech University, Nanjing 211816, China; 201861111008u@njtech.edu.cn \\ * Correspondence: shao.j.z@hotmail.com
}

Citation: Shao, J.; Yang, M.; Liu, G.; Li, Y.; Luo, D.; Tan, Y.; Zhang, Y.; Song, Q. Urban Sub-Center Design Framework Based on the Walkability Evaluation Method: Taking Coomera Town Sub-Center as an Example. Sustainability 2021, 13, 6259. https:// doi.org/10.3390/su13116259

Academic Editor: Luigi Dell'Olio

Received: 31 March 2021

Accepted: 25 May 2021

Published: 1 June 2021

Publisher's Note: MDPI stays neutral with regard to jurisdictional claims in published maps and institutional affiliations.

Copyright: (c) 2021 by the authors. Licensee MDPI, Basel, Switzerland. This article is an open access article distributed under the terms and conditions of the Creative Commons Attribution (CC BY) license (https:// creativecommons.org/licenses/by/ $4.0 /)$.

\begin{abstract}
As current society's reflection on the rapid development of motorization and increasing emphasis on the ecological environment, the study of walkable cities has become one of the key points of urban sustainable design. Creating a walkable city is an effective way to build a low-carbon and healthy city. With the development of cities, walkability concepts and theories are constantly being given new life, and research methods and design strategies continue to be updated. A city's walkability and walkability index have become current research hotspots. Based on prior research on walkability and related urban policies, this study selects Coomera Town on the Gold Coast of Queensland, Australia, as the research area because of Coomera Town policy regulations and environmental requirements. This study utilizes traditional qualitative and quantitative research methods, machine mining technology, and the deep learning big data analysis technology to conduct thematic design research in a real place. Its combines walkability evaluation with walkability design to construct a walkable city in a targeted manner. This provides a reference for related city design in the future.
\end{abstract}

Keywords: walkability; urban sustainability; walkability evaluation; urban sub-center

\section{Introduction}

Cities and towns worldwide, whether in developing or developed countries, face increasing problems such as suburban sprawl, growing vehicle use, loss of landscapes and ecosystems, and rising social inequalities resulting from population growth, urbanization, and economic development [1-5]. Therefore, one major goal of urban design is to reduce automobile dependency to address viability and sustainability issues [2]. Furthermore, urban sustainability has become a focal point and goal in the urban design and policymaking fields, attracting the attention of both urban designers and politicians. At the same time, as walking is conducive to human health, community vitality, and the natural environment, people have gradually adopted the concepts of sustainable development and people-oriented walkability. Together, these constitute an important practical method for coping with energy shortages and climate change, reducing carbon emissions and environmental pollution, and improving safety.

The South East Queensland Regional Plan [6] was created to manage regional growth and change in the most sustainable way to protect and enhance quality of life in the region. The plan emphasizes the establishment of healthy and safe communities in South East Queensland by implementing best practice urban design to create built environments that enable walking and cycling, support community safety, and provide adequate shade. Public transport will provide easy access for the whole community by connecting other neighborhood communities, including those who do not have access to a private vehicle or choose not to drive, with the local center. [6]. 
Determining how to grow and expand the city's walkability framework from 'smallscale' neighborhood centers has received considerable critical attention [7]. As LlewelynDavis [8] argues, establishing a sustainable residential community requires considering specific requirements at the local level.

Therefore, this study combines urban livability with urban sub-centers with a commitment to provide a conceptual walkability framework for urban sub-center design based on specific local requirements. This framework is used for walkable community design in Coomera town, Gold Coast, Queensland, Australia, using the walkability evaluation design (WED) method. The aim is to provide a humanized living space connected by walking that encourages people to choose to walk, cycle, and use public transportation. The results can provide a reference for future research.

\section{Literature Review}

This study analyses relevant documents on urban walkability for 2011-2021 period in the SCI core set database using text mining technology. It employs VOSviewer to extract keywords to obtain the research results and predict future research trends for researchers. The research hotspots are shown in Figure 1. Using network visualization, each point on the map has a color based on the density of elements around that point. Points with greater density are closer to red, while those with lesser density are closer to blue. The walkability keyword cluster view shows that previous research key words were "city", "accessibility", "quality", and "street". The previous research mainly focused on urban walkability theories, walkability associated objects, and methods of evaluating the walkability of an urban environment. However, the walking keywords "neighborhood environment walkable", "environmental attribute", and "residential density" are closer to blue, indicating that research on the association of health, environment, and walkability should be strengthened.

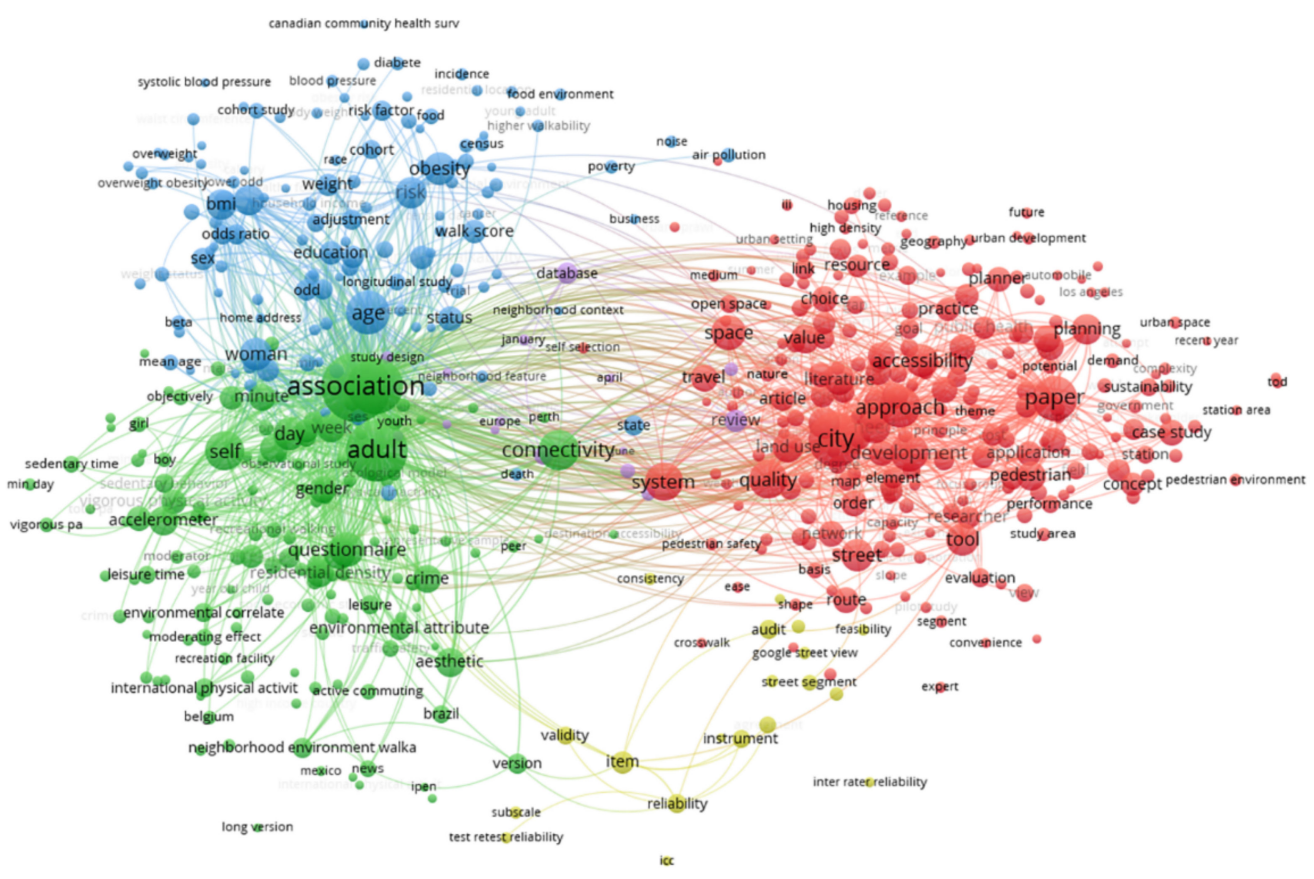

Figure 1. Network visualization of hotspot for walking research in the last 10 years.

Thus, existing international walkability research mainly focused on the design theory and practical work of the urban walkability environment $[9,10]$, such as development of walkability concepts and theories, formulation and promotion of national walkability policies, and factors influencing walkability [11]. In the mid-20th century, many famous scholars put forward the concept of urban walkability and related theories (Table 1). Ac- 
cordingly, the Radburn model, traffic calming [12], woonerf [13], and walkable city [14] became the mainstream theories of walkability research. At the same time, the walkability concept and theory were tested in some western urban centers, such as the United States [12], United Kingdom, Canada, Netherlands, Denmark, and Singapore [15]. These countries introduced guidelines for designing pedestrian priority roads in cities and communities to promote the design and construction of sidewalks, and they have achieved wide-ranging influence [16]. Among them, walkability city is the hotspot in theoretical research on urban livability at this stage.

Table 1. Main walkability concepts and theories.

\begin{tabular}{|c|c|c|c|c|c|}
\hline Time & Policy & Presenter & Highlights & $\begin{array}{l}\text { Implementing } \\
\text { Country }\end{array}$ & Effect \\
\hline 1928 & $\begin{array}{l}\text { Radburn } \\
\text { model }\end{array}$ & Radburn & $\begin{array}{l}\text { Create a traffic model that } \\
\text { separates people and vehicles, } \\
\text { which is specifically manifested in } \\
\text { setting up independent motorized } \\
\text { traffic flow lines and pedestrian } \\
\text { (bicycle) traffic flow lines [17]. }\end{array}$ & United States & $\begin{array}{l}\text { Some new city constructions } \\
\text { in the United States in the } \\
1930 \text { s were based on } \\
\text { Radburn model, such as the } \\
\text { Senasai Garden City and } \\
\text { cites in Ohio, Maryland and }\end{array}$ \\
\hline 1960 & $\begin{array}{l}\text { Traffic } \\
\text { calming }\end{array}$ & $\begin{array}{c}\text { Colin } \\
\text { Buchanan }\end{array}$ & $\begin{array}{l}\text { Completely separate motor } \\
\text { vehicles from pedestrians, } \\
\text { redevelop vehicle restricted areas } \\
\text { in urban areas, and establish } \\
\text { pedestrian corridors [13]. }\end{array}$ & $\begin{array}{l}\text { Germany, } \\
\text { Netherlands, and } \\
\text { United Kingdom }\end{array}$ & $\begin{array}{l}\text { Tew Jersey, Wisconsin }[17] \text {. } \\
\text { The concept of traffic } \\
\text { calming has aroused strong } \\
\text { response and controversy in } \\
\text { the United Kingdom and } \\
\text { other European and } \\
\text { American countries [18]. } \\
\text { However, it has not become } \\
\text { a government policy for a } \\
\text { long time. }\end{array}$ \\
\hline 1969 & Woonerf & Niek de Boer & $\begin{array}{l}\text { Woonerf is a derivative of the idea } \\
\text { of traffic tranquility, emphasizing } \\
\text { that pedestrians, cyclists, and } \\
\text { vehicles share the street space in } \\
\text { the urban space }[10,19] .\end{array}$ & $\begin{array}{l}\text { Canada, United } \\
\text { Kingdom, } \\
\text { Germany, France, } \\
\text { Japan, and } \\
\text { Singapore }\end{array}$ & $\begin{array}{l}\text { In 1976, woonerf became a } \\
\text { guide for urban road design } \\
\text { in the Netherlands [20]. It } \\
\text { was gradually accepted by } \\
\text { most European and Asian } \\
\text { countries and became one of } \\
\text { the main forms of street } \\
\text { design for modern, new } \\
\text { residential areas. }\end{array}$ \\
\hline 2014 & Walkable city & Jeff Speck & $\begin{array}{l}\text { Emphasis is on improving the } \\
\text { setting of safe pedestrian } \\
\text { passages and reasonable space } \\
\text { allocation of pedestrian facilities } \\
\text { to make the city more walkable } \\
\text { while ensuring travel safety and } \\
\text { sustainable urban } \\
\text { development [14]. }\end{array}$ & $\begin{array}{l}\text { United States, } \\
\text { United Kingdom, } \\
\text { China, Singapore, } \\
\text { etc. }\end{array}$ & $\begin{array}{l}\text { The concept of a walkable } \\
\text { city has become a hotspot of } \\
\text { urban designresearch in } \\
\text { recent years }[14,20] .\end{array}$ \\
\hline
\end{tabular}

The research on walkability-related objects can be summarized into two main dimensions: society and environment. At the social level, some scholars focused on health and age-appropriate perspectives. Early research started with health: from revealing the impact of the built environment on walking ability and human health [21-24] to analyzing the correlation between street network elements and physical health [23], and then selecting health indicators to evaluate the walkability of the road-network system [25]. Some extended their work to use travel characteristics, efficiency, and needs of the elderly [26] and children [27] as research indicators and then proposed an optimization strategy for a safe, friendly, and age-appropriate walkability system. In particular, Professor Tom Yates of the University of Leicester found that "brisk walking is beneficial to fight against the new coronavirus infection. Obesity and weakness are the key risk factors for COVID-19 infection." [28] 
Walkable cities can also help reduce infectious diseases infection risks. Research on the environmental dimension revolved around climate adaptation, low-carbon orientation, etc. Algeciras, J.A.R, Consuegra, L.G, and Matzarakis. A [29] analyzed the impact of street layout on thermal comfort. Marvin, Yang, Zheng, and Rutherford [30,31] established an evaluation system that integrates pedestrian space and microclimate elements, and they perfected the research on the pedestrian system's climate adaptation mechanism. In the context of developing a green and low-carbon society, some scholars have focused on analyzing the correlation between low-carbon travel and pedestrian networks, exploring the layout of low-carbon-oriented public service facilities [32], proposing a slow-travel friendly street space model [33], and predicting the future directions of low-carbon cities' sizes and road-network density [34]. Thus, existing research focused on walkability from a single perspective. However, urban walkability is complex and usually affected by many factors. Therefore, it is necessary to coordinate the relevant elements of urban walkability and solve the actual situation from a comprehensive perspective.

Existing methods to evaluate walkability focus on the levels of various indicators through the analytic hierarchy process. However, there is a lack of combination of multiple big data, construction of a comprehensive evaluation indicator system, or improvement of future specific planning and design schemes [35-38]. Many scholars used expert interviews, questionnaire surveys, field observations, etc., to obtain single-latitude walking space data to evaluate street walking ability. Therefore, the calculation results usually only represent a certain aspect of street walkability. Simultaneously, due to lack of consideration of other urban spatial factors, the data and results may be biased [31]. At present, measurement research based on big data evaluation is still in its infancy but has achieved good results [11,28,34-36]. Google Street View images can be used to measure the relevant index values of the pedestrian space environment, and they have the advantages of high precision and high efficiency in terms of cost and collection time [36]. Further, the geographic information system and global positioning system methods help obtain big data for empirical research. The above methods provide a data basis for studying the pedestrian street environment [34,39]. Therefore, integrating deep learning and data-mining methods based on hierarchical analysis to obtain multiple big data is useful for street walkability research.

Therefore, this research selects walkable cities as theoretical guidance while using the analytic hierarchy process, deep learning algorithm, and data-mining methods to comprehensively study urban walkability in combination with actual projects.

\section{Methods}

This research adopts a qualitative and quantitative research strategy. The literature review examines principles and concepts of urban design practice from relevant research papers and documents. By analyzing this relevant information, this study intends to limit generalization by focusing on guidelines for urban walkability that can be implemented at the residential communities' urban design level. Moreover, for this study, it is helpful to comprehend why building a walkable city is imperative and how walkability variables can contribute to urban sub-centers' sustainable development. Here, the case study method [40] can produce a formal urban design framework for a real place to achieve the research objectives and answer the research question. Therefore, this research involves a single case study in the field of urban design practice. Based on the inductive research and case study methods, Walkability Evaluation Design (WED) method is proposed to guide the urban walkability theme design.

WED guides specific urban walkability design based on the evaluation results, and it includes two parts: analysis of walkability evaluation results and walkability project design, which is further divided into five steps: (1) Select walkability evaluation elements through the big data clustering method and build a walkability evaluation system. (2) Judge and analyze the evaluation result. (3) Use the walkability evaluation index score to carry out urban walkability design. In particular, walking distance, walkability non-linear coefficient, etc., are calculated by directly crawling digital geographic information using 
Google Maps. The sky visibility index, walkability color richness index, etc., are obtained through Google Street View combined with visual images using a fully convolutional network (FCN) for street-view elements' proportion recognition calculation (Figure 2).

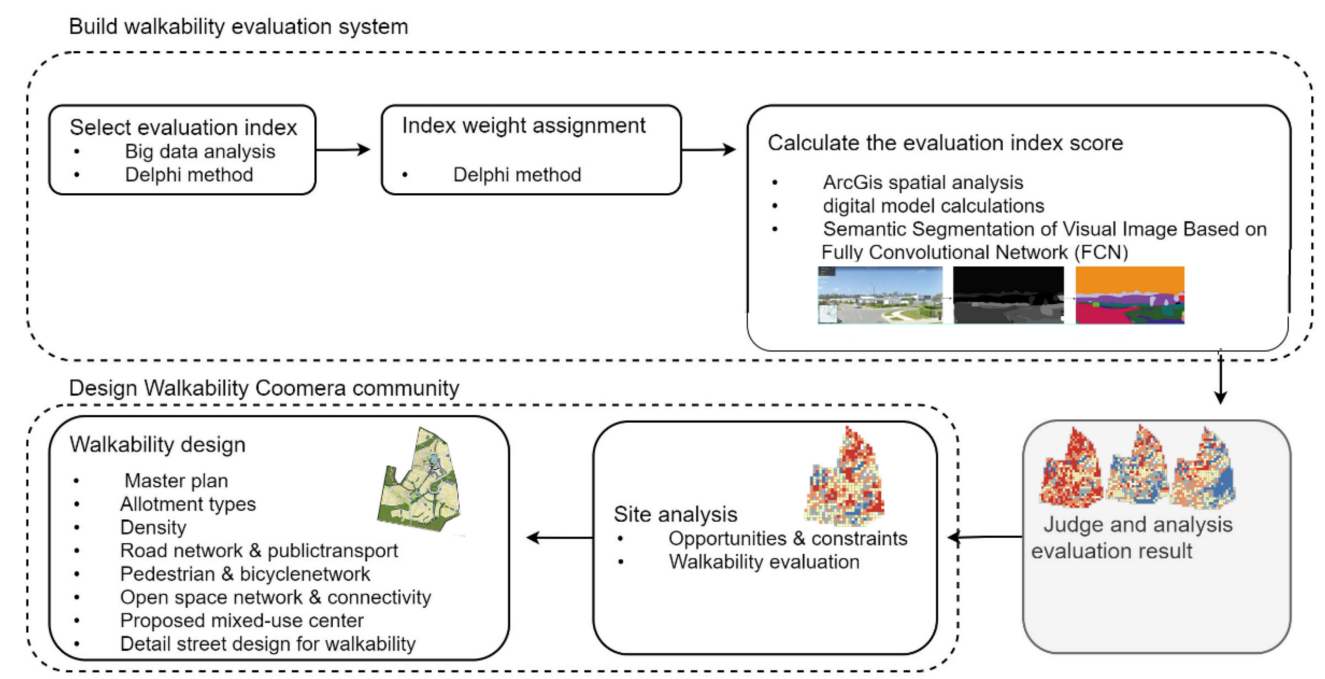

Figure 2. Flow chart of walkability evaluation design method.

\section{Building a Walkability Evaluation System}

Llewelyn-Davis [8] noted that "how comfortable a place feels are a matter of the design and its social characteristics". The urban sub-center design should thus ensure that buildings, streets, and places are of human scale; provide convenient transfer facilities between a variety of modes of transport; and use high-quality landscaping to strengthen good perceptions of a place [41]. Based on the literature review and regional and local planning contexts and documents [42-44], including the South East Queensland Regional Plan 2009-2031 and Gold Coast City Council Planning and Design Documents, this study attempts to examine an urban walkability environment by extracting a series of walkability influencing factors and evaluation criteria for the walkability evaluation index system.

\subsection{Selecting Evaluation Indexes}

\subsubsection{Density}

City density is a key attribute of the walkability of a city's sub-center. It refers to not only population density but also the building density, business density, and distribution density of public facilities [45-52]. The degree of overlap between building density and population distribution density [45] is relatively high, and the building density of urban sub-centers should be low to medium (Table 2). Both low and medium densities are optimal forms that maximize density while minimizing perceived intensity or overcrowding. Therefore, starting from the need for urban sub-centers to enhance their attractiveness and meet the work and life needs of nearby suburban residents, the road intersection density index, road-network accessibility index, and point-of-interest (POI) density index are necessary for studying urban walkability. 
Table 2. Density matrix of large sites.

\begin{tabular}{|c|c|c|c|c|}
\hline \multirow{2}{*}{ Location } & \multirow{2}{*}{ Setting } & \multicolumn{3}{|c|}{ Predominant Housing Type } \\
\hline & & Detached \& Linked Houses & Terraced Houses \& Flats & Mostly Flats \\
\hline \multirow{10}{*}{ Site within Town Center } & Central & & & $\begin{array}{c}240-1100 \\
\mathrm{~h} / \mathrm{ha} \\
240-435 \mathrm{u} / \mathrm{ha} \\
\text { Ave. } 2.7 \mathrm{~h} / \mathrm{u}\end{array}$ \\
\hline & \multirow{3}{*}{ Urban } & & 200-450 h/ha & $450-700 \mathrm{~h} / \mathrm{ha}$ \\
\hline & & & 55-175 u/ha & $165-275 \mathrm{u} / \mathrm{ha}$ \\
\hline & & & Ave. $3.1 \mathrm{~h} / \mathrm{u}$ & Ave. $2.7 \mathrm{~h} / \mathrm{u}$ \\
\hline & \multirow{3}{*}{$\begin{array}{c}\text { Urban } \\
\text { Sub-Center }\end{array}$} & & $220-350 \mathrm{~h} / \mathrm{ha}$ & $350-450 \mathrm{~h} / \mathrm{ha}$ \\
\hline & & & $45-125 \mathrm{u} / \mathrm{ha}$ & 125-180 u/ha \\
\hline & & & Ave. $3.8 \mathrm{~h} / \mathrm{u}$ & Ave. $2.8 \mathrm{~h} / \mathrm{u}$ \\
\hline & \multirow{3}{*}{ Sub-Urban } & & $240-250 \mathrm{~h} / \mathrm{ha}$ & $250-350 \mathrm{~h} / \mathrm{ha}$ \\
\hline & & & $35-60 \mathrm{u} / \mathrm{ha}$ & $80-120 \mathrm{u} / \mathrm{ha}$ \\
\hline & & & Ave. $4.2 \mathrm{~h} / \mathrm{u}$ & Ave. $3.0 \mathrm{~h} / \mathrm{u}$ \\
\hline \multirow{9}{*}{$\begin{array}{l}\text { Sites along Transport Corridors } \\
\text { and Sites close to a Town Center }\end{array}$} & \multirow{3}{*}{ Urban } & & $200-300 \mathrm{~h} / \mathrm{ha}$ & $300-450 \mathrm{~h} / \mathrm{ha}$ \\
\hline & & & 50-110 u/ha & 100-150 u/ha \\
\hline & & & Ave. $3.7 \mathrm{~h} / \mathrm{u}$ & Ave. $3.0 \mathrm{~h} / \mathrm{u}$ \\
\hline & \multirow{3}{*}{$\begin{array}{c}\text { Urban } \\
\text { Sub-Center }\end{array}$} & $150-200 \mathrm{~h} / \mathrm{ha}$ & $200-280 \mathrm{~h} / \mathrm{ha}$ & \multirow{6}{*}{$\begin{array}{l}350-400 \mathrm{~h} / \mathrm{ha} \\
95-150 \mathrm{u} / \mathrm{ha} \\
\text { Ave. } 3.0 \mathrm{~h} / \mathrm{u}\end{array}$} \\
\hline & & $30-55 \mathrm{u} / \mathrm{ha}$ & $50-85 \mathrm{u} / \mathrm{ha}$ & \\
\hline & & Ave. $4.3 \mathrm{~h} / \mathrm{u}$ & Ave. $3.6 \mathrm{~h} / \mathrm{u}$ & \\
\hline & \multirow{3}{*}{ Sub-Urban } & $150-200 \mathrm{~h} / \mathrm{ha}$ & 200-250 h/ha & \\
\hline & & $30-50 \mathrm{u} / \mathrm{ha}$ & $50-80 \mathrm{u} / \mathrm{ha}$ & \\
\hline & & Ave. $4.6 \mathrm{~h} / \mathrm{u}$ & Ave. $3.5 \mathrm{~h} / \mathrm{u}$ & \\
\hline Currently Remote Sites & Sub-Urban & $\begin{array}{c}150-200 \mathrm{~h} / \mathrm{ha} \\
30-65 \mathrm{u} / \mathrm{ha} \\
\text { Ave. } 4.4 \mathrm{~h} / \mathrm{u}\end{array}$ & & \\
\hline
\end{tabular}

\subsubsection{Open Space}

Open spaces in urban areas are mainly manmade spaces, primarily including urban parks, neighborhood spaces, sports fields, playgrounds, and squares [53,54]. Such open space types have plenty of surrounding natural resources and diverse space types, providing beautifully landscaped open spaces. Greenways, which are used as movement corridors, introduce natural landscapes into the town's open spaces, effectively creating a relationship between manmade and natural spaces. In addition, green open spaces greatly improve the comfort of the walking environment, especially in terms of sky visibility and tree coverage, and reduce the traffic pollution exposure index, mitigate carbon emissions and climate change, and balance humans and wildlife.

\subsubsection{Road Network and Public Transport}

The construction of urban sub-centers must be linked with the high-capacity rapid rail transit ring and the sub-centers' urban transit-oriented development [55-57]. Welldeveloped public transportation network systems are important supports for the development of walkable communities. The urban sub-center transport network can be organized within the public transportation network [57], with rail transportation as the main body, ground public transportation as the base, and other modes of transportation as supplementary modes (Table 3). Public transportation hubs should overlap with the urban public activity centers at all levels in the urban space and enrich the diversity of public transportation and density of public transportation stations. Such transportation can greatly improve the convenience of the walking environment, avoid car dependency, and reduce consumption of fossil fuels in urban areas, thus creating a benign urban transportation coupling mode in the form of transit-oriented development. 
Table 3. Catchment areas for public transport [48,55-57].

\begin{tabular}{cccccc}
\hline Type & Minibus & Bus & Guided Bus & Light Rail & Rail \\
\hline Stop interval $(\mathrm{m})$ & 200 & 200 & 300 & 600 & $1000+$ \\
Corridor width/area & 800 & 800 & 800 & 1000 & $2000+$ \\
served (m) & $320-640$ & $480-1760$ & $1680-3120$ & $4800-9000$ & $2400-24,000$ \\
Catchment per stop (m) & 3200 \\
\hline
\end{tabular}

\subsubsection{Pedestrian and Bicycle Network}

A pedestrian and bicycle network should be designed for low speeds so that pedestrians, cyclists, and vehicles can mix safely. Road intersection density, non-linear walkability distance, and road feasibility are the most important factors. Road intersection density and non-linear walkability distance are negatively correlated with pedestrian and bicycle networks, while road feasibility is positively correlated. In addition to providing a wellconnected pedestrian network, it is important to ensure public transport connectivity in larger cities or regions, which can be connected via other modes of transport with reasonable times and distances (Table 4), such as buses, trams, subways, and trains [56], to create a convenient pedestrian and bicycle transition network.

Table 4. Comparison of the travel time and cost for transportation.

\begin{tabular}{cccccc}
\hline Type & $\begin{array}{c}\text { Distance } \\
\mathbf{( k m )}\end{array}$ & $\begin{array}{c}\text { Speed } \\
\mathbf{( k m} / \mathbf{h})\end{array}$ & $\begin{array}{c}\text { Waiting } \\
\text { Time (min) }\end{array}$ & $\begin{array}{c}\text { Transfer } \\
\text { Time (min) }\end{array}$ & $\begin{array}{c}\text { Travel Time } \\
\mathbf{( m i n )}\end{array}$ \\
\hline Walk & $0 \sim 1$ & 4 & - & - & $10 \sim 20$ \\
Cycle & $1 \sim 6$ & 15 & - & - & $10 \sim 30$ \\
Car & $>2$ & 36 & - & 5 & $>30$ \\
Bus & $2 \sim 10$ & 18 & 4 & - & $30 \sim 60$ \\
Taxi & $2 \sim 13$ & 36 & $1 \sim 3$ & $1 \sim 3$ & $10 \sim 60$ \\
Subway & $>1$ & 37 & & $>10$
\end{tabular}

\subsubsection{Walking within the Landscape}

A systematic network of walking lanes and the surrounding environment needs to be considered. Natural landscape areas and large open spaces around the town combined with the historical and cultural areas, landmarks, squares of important activity, and important public facilities within the urban sub-center are systematically connected to form the pedestrian system structure of the urban sub-center. Such areas reveal the beauty of the city and are connected by walking routes so that the public can experience the city's natural beauty and human connotations through slow movement; they create a walkable microclimate environment. Different streets have different sights, such as local residential streets, approaches to transit stations, and rear lanes (Table 5). A rich form of walking space is formed with seasonal variations matching different species of vegetation (Figure 3) to increase the color pleasure and color richness indexes of the walking environment. 
Table 5. Plant configurations for different roads.

\begin{tabular}{cll}
\hline Type & & \multicolumn{1}{c}{ Plant Configuration } \\
\hline Main street & Wide low trees are planted in the middle of the road to relieve long-term \\
driving fatigue and prevent pedestrian crossing. \\
Trees are planted in rows at entrances and turns to guide the direction of \\
traffic, and they should not be planted at intersections to avoid \\
blocking vision. \\
The green island at intersections is dominated by lawns and groundcovers, \\
and it is appropriately decorated with low evergreen trees, flowering \\
shrubs, and perennial flowers.
\end{tabular}
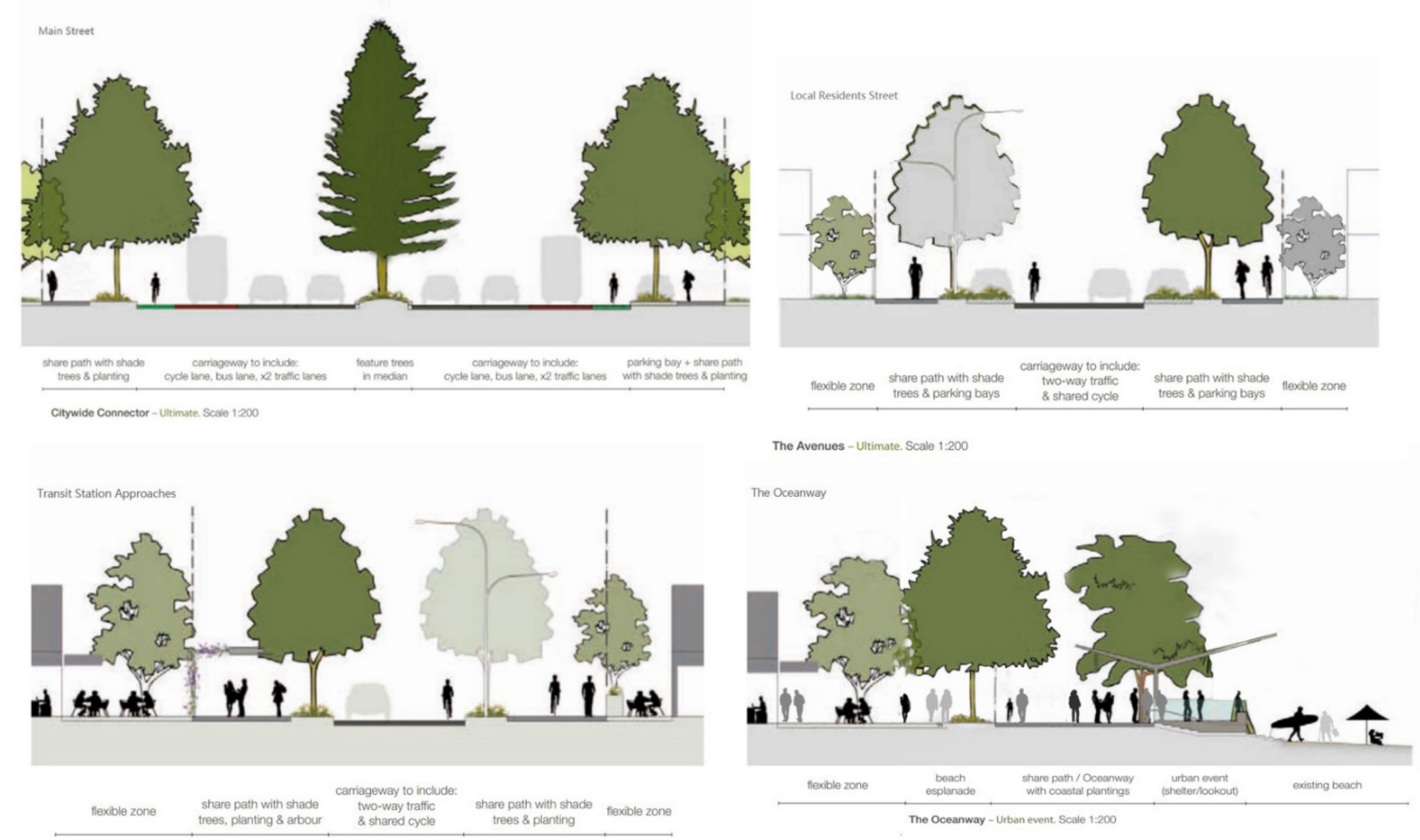

Figure 3. Street types of urban sub-center. 


\subsubsection{Path Security}

As is stated in the Wisconsin State Highway Plan [46], a safe and accessible street environment is one where pedestrians, cyclists, and public transportation vehicles have a higher quality pedestrian environment than private cars do. There should be sufficient space between the building framework and the curb for safe and comfortable accommodation of sports spaces and streetscape elements to provide good shelter for pedestrians. It is necessary to reduce walking risks by ensuring safe distance and setting up walkability safety infrastructure, because vehicles pose the greatest threat to a safe urban walkability environment. Therefore, the vehicle interference index and walkability facility safety index are selected as design indicators of the walkability safety index. These elements are coordinated and shaped so that the pedestrian network is closely connected with other modes of transportation, such as buses, trams, and subways, without interference and danger, thus reducing dependence on cars.

\subsubsection{Summary}

Starting from the goal of creating an urban walkability environment, the six factors influencing such an environment include the walkability convenience index, public transportation convenience index, functional service convenience index, walkability comfort index, walkability safety index, and walkability color index. Further, the walkability comfort index, walkability convenience index, and walkability safety index are directly related to urban walkability. The public transportation convenience index, functional service convenience index, and walkability color index have an indirect influence. The walkability comfort index, public transportation convenience index, and walkability safety index have a greater degree of influence, while the other factors have lesser influence. Each element's degree of influence is shown in Figure 4.

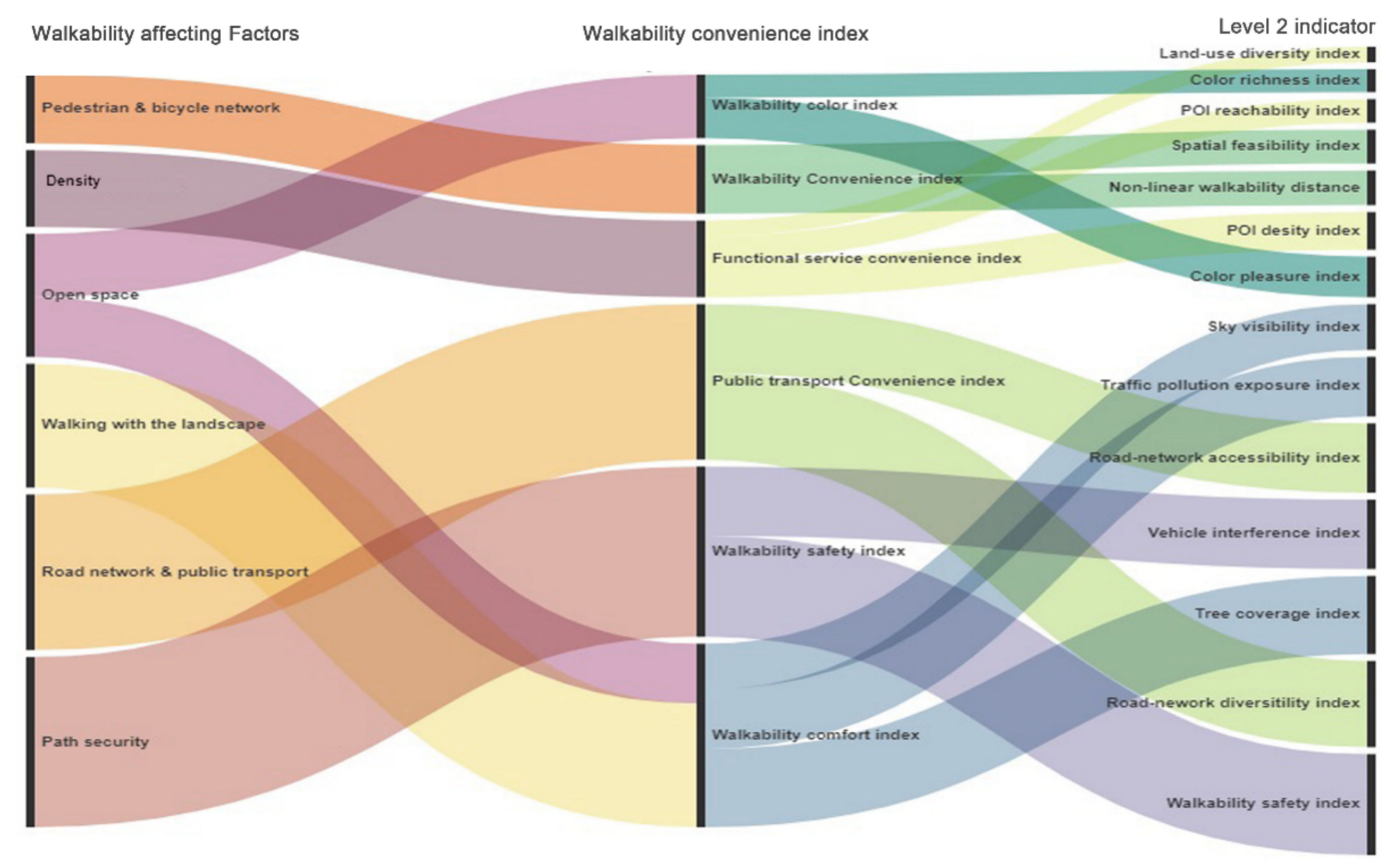

Figure 4. The relationship between walkability affecting factors.

\subsection{Obtain Data on Evaluation Indicators}

Based on the ArcGIS raster map, each sampling point on the map has a spatial feasibility index, sky visibility index, tree coverage index, motor traffic influence, color pleasure index, and color richness index. First, Google Street View maps are obtained and analyzed using Python. Then, for the proportion of image elements obtained from photos using FCN (Figure 5), such as the sky, buildings, roads, paving, safety facilities, 
cars, and plants, we perform normalization, evaluate photo information, and multiply the evaluation score by the weight to obtain the index distribution map of Coomera. The remaining indicators are obtained from the OpenStreetMap website, combined with digital processing to obtain indicator scores, and data visualization is performed through ArcGIS.
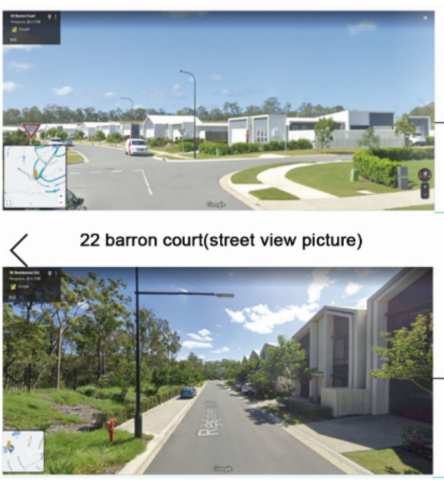

Residences cct (street view picture)

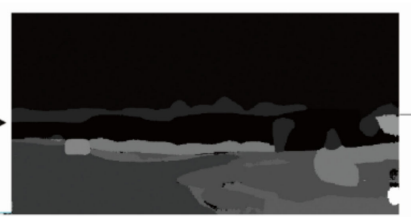

22 barron court (monochrome processing diagram)

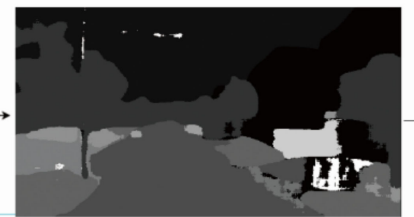

Residences cct (monochrome processing diagram)

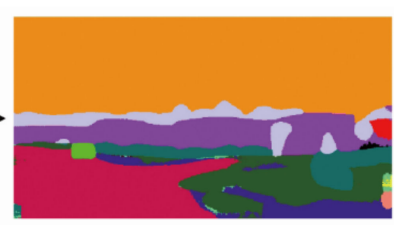

22 barron court(FCN diagram)

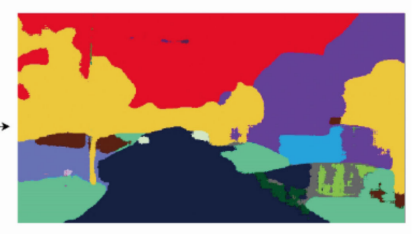

Residences cct (FCN diagram)

Figure 5. Interpret Coomera photo information by FCN.

\subsection{Determin the Evaluation Indicators and Standards}

Many factors influence the urban walkability environment, and it has the characteristics of multiple and complex data. Therefore, qualitative and quantitative research methods are adopted through the analytic hierarchy process. This is combined with expert experience and judgement as well as quantitative analysis through machine learning to construct a relatively scientific evaluation method (Table 6).

Table 6. Walkability evaluation indicators [35,38,39,58,59].

\begin{tabular}{|c|c|c|c|c|}
\hline $\begin{array}{c}\text { Level } 1 \\
\text { Indicator }\end{array}$ & Level 2 Indicator & Formula & Explanation & Correlation \\
\hline \multirow{3}{*}{$\begin{array}{l}\text { Walkability } \\
\text { convenience } \\
\text { index }\end{array}$} & $\begin{array}{l}\text { Road intersection } \\
\text { density index }\end{array}$ & $R D I_{n}=\frac{C \mathrm{n}}{A n}=\frac{\sum_{i=1}^{1} c_{i}}{\sum_{i=1}^{1} a_{i}}$ & $\begin{array}{c}C_{n} \text { is the number of road intersections in the } \\
\text { unit space, and } A_{n} \text { is the best urban land } \\
\text { area with public transport services. }\end{array}$ & - \\
\hline & $\begin{array}{l}\text { Non-linear } \\
\text { walkability } \\
\text { distance }\end{array}$ & $P R D=\frac{L_{i j}}{M_{i j}}$ & $\begin{array}{l}L_{i j} \text { is the actual road length between } i \text { and } j \\
\text { points on the walking road, and } M_{i j} \text { is the } \\
\text { graph length between } i \text { and } j \text { points with a } \\
\text { length range of } 1.2-1.5 \mathrm{~m} \text {. }\end{array}$ & - \\
\hline & $\begin{array}{l}\text { Spatial feasibility } \\
\text { index }\end{array}$ & $S F I_{n}=\frac{w_{n}}{R_{n}}=\frac{\sum_{i=1}^{i} W_{i}}{\sum_{i=1}^{i} \gamma_{i}}$ & $\begin{array}{l}W_{n} \text { is the total number of pixels in the } \\
\text { street-view picture } n \text {, and } R_{n} \text { is the total } \\
\text { number of pixels in the street-view picture. }\end{array}$ & + \\
\hline \multirow{2}{*}{$\begin{array}{l}\text { Public } \\
\text { transport } \\
\text { convenience } \\
\text { index }\end{array}$} & $\begin{array}{c}\text { Road-network } \\
\text { accessibility index }\end{array}$ & $R A I_{n}=\frac{L n}{A n}=\frac{\sum_{i=1}^{1} l_{i}}{\sum_{i=1}^{1} a_{i}}$ & $\begin{array}{l}L_{n} \text { is the total length of the central road line } \\
\text { with bus lines, and } A_{n} \text { is the best urban land } \\
\text { area with public transport services. }\end{array}$ & + \\
\hline & $\begin{array}{l}\text { Road-network } \\
\text { diversity index }\end{array}$ & $P R I_{n}=\frac{R n}{A n}=\frac{\sum_{i=1}^{1} r_{i}}{\sum_{i=1}^{1} a_{i}}$ & $\begin{array}{c}R_{i} \text { is the number of public transport routes } \\
\text { in unit space } n \text {, and } A_{n} \text { is the best urban } \\
\text { land area with public transport services in } \\
\text { the } 400-\mathrm{m} \text { range. }\end{array}$ & + \\
\hline
\end{tabular}


Table 6. Cont.

\begin{tabular}{|c|c|c|c|c|}
\hline $\begin{array}{l}\text { Level } 1 \\
\text { Indicator }\end{array}$ & Level 2 Indicator & Formula & Explanation & Correlation \\
\hline \multirow{3}{*}{$\begin{array}{l}\text { Functional } \\
\text { service } \\
\text { convenience } \\
\text { index }\end{array}$} & $\begin{array}{l}\text { POI reachability } \\
\text { index }\end{array}$ & $\begin{array}{c}P R I_{n}= \\
p_{i} \times 0.6+p_{j} \times 0.3+p_{k} \times 0.1\end{array}$ & $\begin{array}{c}P_{i} \text { is the number of POIs in the } 300-\mathrm{m} \text { range, } \\
P_{j} \text { is the number of POIs in the } 600-\mathrm{m} \text { range, } \\
\text { and } P_{k} \text { is the number of POIs in the } \\
900-\mathrm{m} \text { range. }\end{array}$ & + \\
\hline & $\begin{array}{l}\text { Land-use } \\
\text { diversity index }\end{array}$ & $\begin{array}{c}L D I_{n}= \\
-\sum_{j=1}^{J}\left(\frac{P_{i}}{\sum_{j=1}^{J} P j} \times \ln \left(\frac{P_{i}}{\sum_{j=i}^{j} P_{j}}\right)\right)\end{array}$ & $\begin{array}{c}P_{i} \text { is the street area in cell space } n \text { that } \\
\text { belongs to the } i \text { type, and } J \text { is the total } \\
\text { number of land types in the cell space } \\
\text { enclosure. }\end{array}$ & + \\
\hline & POI density index & $P D I_{n}=\frac{P n}{A n}=\frac{\sum_{i=1}^{1} p_{i}}{\sum_{i=1}^{1} a_{i}}$ & $\begin{array}{c}P_{n} \text { is the number of POIs in the unit space, } \\
\text { and } A_{n} \text { is the area of urban land serviced by } \\
\text { public transport. }\end{array}$ & + \\
\hline \multirow{3}{*}{$\begin{array}{l}\text { Walkability } \\
\text { comfort index }\end{array}$} & $\begin{array}{l}\overline{\text { Sky }} \overline{\text { visibility }} \overline{-} \\
\quad \text { index }\end{array}$ & $S V I_{n}=\frac{V_{n}}{A n}=\frac{\sum_{i=1}^{i} g_{i}}{\sum_{i=i}^{i} l_{i}}$ & 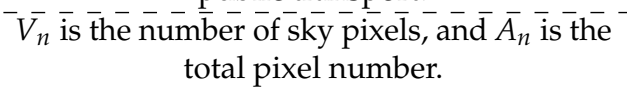 & + \\
\hline & $\begin{array}{l}\text { Traffic pollution } \\
\text { exposure index }\end{array}$ & Caver $=\sum \mathrm{CiTi}$ & $\begin{array}{c}C_{\text {aver }} \text { is the average exposure level for } \\
\text { individual } \mathrm{PM}, \mathrm{min} . \mathrm{g} / \mathrm{m}^{3} ; C_{i} \text { is the average } \\
\mathrm{PM} \text { concentration of the individual's place } \\
\text { of activity during time period } i, \mathrm{sg} / \mathrm{m}^{3} \text {; and } \\
T_{i} \text { is the commute time for time } \\
\text { period } i, \text { min. }\end{array}$ & - \\
\hline & $\begin{array}{l}\text { Tree coverage } \\
\text { index }\end{array}$ & $G V I_{n}=\frac{G n}{A n}=\frac{\sum_{i=1}^{i} g_{i}}{\sum_{i=1}^{i} a_{i}}$ & $\begin{array}{l}G_{n} \text { is the number of vehicle pixels, and } A_{n} \text { is } \\
\text { the total pixel number. }\end{array}$ & + \\
\hline \multirow{2}{*}{$\begin{array}{l}\text { Walkability } \\
\text { safety index }\end{array}$} & $\begin{array}{l}\overline{\text { Walkability }} \overline{-} \\
\text { facility safety } \\
\quad \text { index }\end{array}$ & $W S I_{n}=\frac{S n}{A n}=\frac{\sum_{i=1}^{1} s_{i}}{\sum_{i=1}^{1} a_{i}}$ & $\begin{array}{l}\text { facilities in the unit space, and } A_{n} \text { is the area } \\
\text { of urban land serviced by public transport. }\end{array}$ & + \\
\hline & $\begin{array}{l}\text { Vehicle } \\
\text { interference index }\end{array}$ & $V I I_{n}=\frac{C_{n}}{R_{n}}=\frac{\sum_{i=1}^{1} c_{i}}{\sum_{i=1}^{1} r_{i}}$ & $\begin{array}{c}C_{n} \text { is the number of vehicle pixels, and } R_{n} \text { is } \\
\text { the total pixel number. }\end{array}$ & - \\
\hline \multirow{2}{*}{$\begin{array}{l}\text { Walkability } \\
\text { colour index }\end{array}$} & $\begin{array}{l}\text { Colour pleasure } \overline{-} \\
\quad \text { index }\end{array}$ & $C R I_{n}=1-\sum_{i=1}^{s} \frac{1}{5} \times A_{i}$ & $\begin{array}{l}A_{i} \text { is the score of the } i \text { dominant color in } \\
\text { Google Street View picture } n \text {. }\end{array}$ & + \\
\hline & $\begin{array}{l}\text { Colour richness } \\
\text { index }\end{array}$ & $C R I_{n}=1-\sum_{i=1}\left(\frac{q_{i}}{\sum_{i=1}^{1} q_{i}}\right)^{2}$ & $\begin{array}{c}q_{i} \text { is the score of the } i \text { dominant color in } \\
\text { Google Street View picture } n \text {, and } i \text { is the } \\
\text { total pixel number. }\end{array}$ & + \\
\hline
\end{tabular}

Note. $\mathrm{POI}=$ point of interest; $\mathrm{PM}=$ particulate matter.

\section{Design Walkability of the Coomera Community}

\subsection{Site Location}

We were commissioned by the Coomera government to propose a hypothetical walkability theme design framework and master plan, based on the Coomera government policy, planning and design documents for the site. As shown in Figure 6, Coomera Greenfield Development is an area of approximately 1000 ha, with a new city located around the Brisbane-Gold Coast Rail link and centered on the Coomera station. Coomera is the fastest growing suburb on the Gold Coast, increasing by $13.8 \%$ per annum on average since 2000. The area was planned as a major 21st-century community for a population of nearly 100,000 permanent residents by 2025 [52]. The Coomera Town Centre will be developed as a real city-center with a retail area forming streetscapes, with a mixed-use development area and a commercial area surrounded by a variety of dense satellite centers and neighborhood communities [51].

The proposed Walkable Coomera Residential Community is located within the Gold Coast City Local Government Area in South East Queensland. The project base is located to the west of the Pacific Motorway and is approximately $50 \mathrm{~km}$ from Brisbane CBD and $35 \mathrm{~km}$ from Surfers Paradise (Figure 6), with a gross area of approximately 112 ha. It is located at a high point from the surrounding landscape and supports numerous gullies that drain to both east and west of Hotham Creek and the Pimpama River. The land has a variety of natural features that have significantly shaped the urban design, including a strong rhythm of valleys and ridges, a series of watercourses, several ridges and valleys with remnant 
vegetation worthy of preservation, ecological corridors connecting to off-subject land natural areas, and elevated portions with magnificent views. Fortunately, the land contains a 40-mwide electricity easement and two existing road reserves: Nambucca Crescent and Kiama Court. It is also adjacent to two existing public open space areas (Heritage Park and the Rifle Range Linear Park) with opportunities for open space connections and landscape screening.

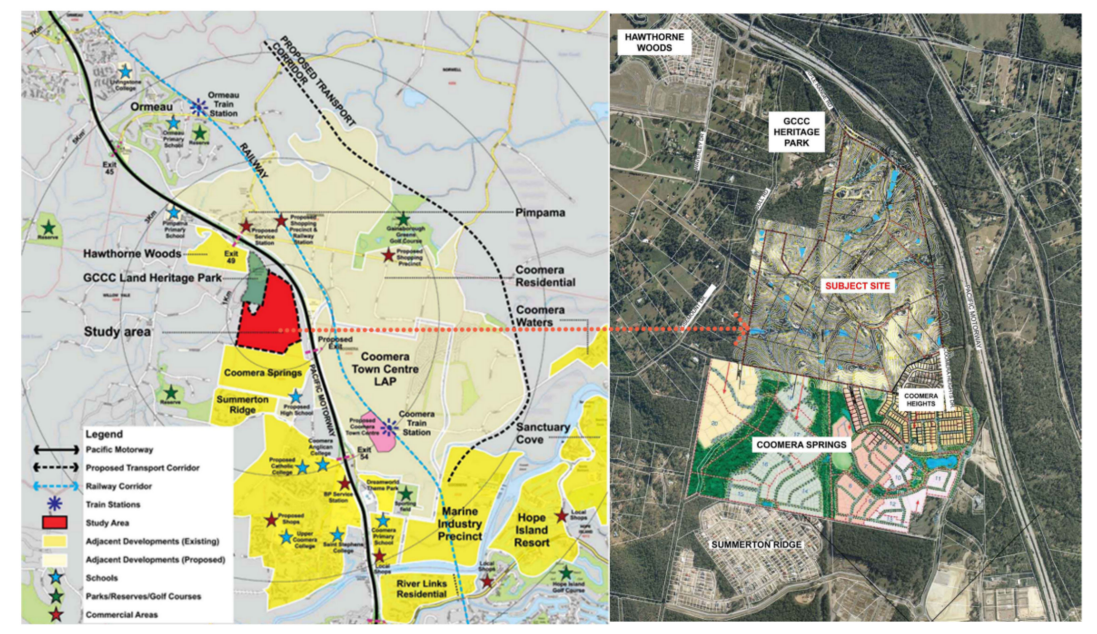

Figure 6. Site location of the Coomera town center.

\subsection{Opportunities and Constraints}

As shown in Figure 7, there are significant constraints for achieving walkability on this land, such as R.L. 65 and an electricity easement, both of which could be elements for breaking the walkable link in the whole site. The land is characterized by steep slopes ranging from $0 \%$ to greater than $25 \%(>1: 4 \mathrm{~m})$. Most of the site is relatively steep, with slopes ranging from $0 \%$ to $20 \%(1: 5 \mathrm{~m})$. The subject land contains some steep slopes, greater than $25 \%$ (>1:4 m), predominantly in the south-eastern corner. Most of the land has slopes less than $20 \%$, with some steeper areas to the proposed buffer to the south. There is possibility of land cutting and filling around the land to enhance the ability to walk and cycle on the roads at different levels.
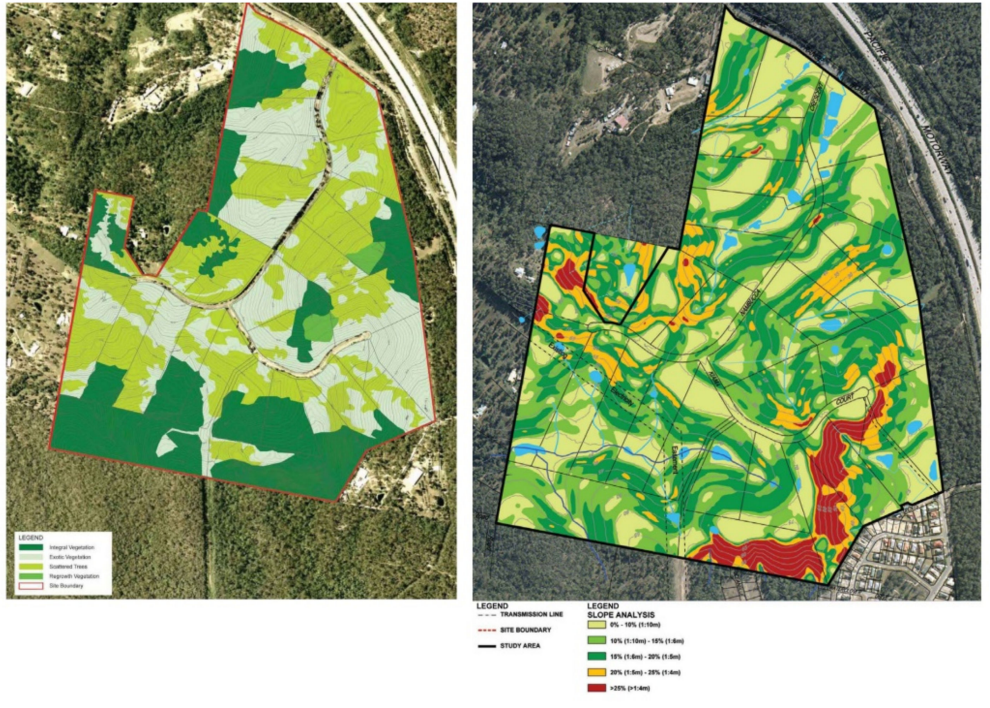

Slope analysis
Flora assessment

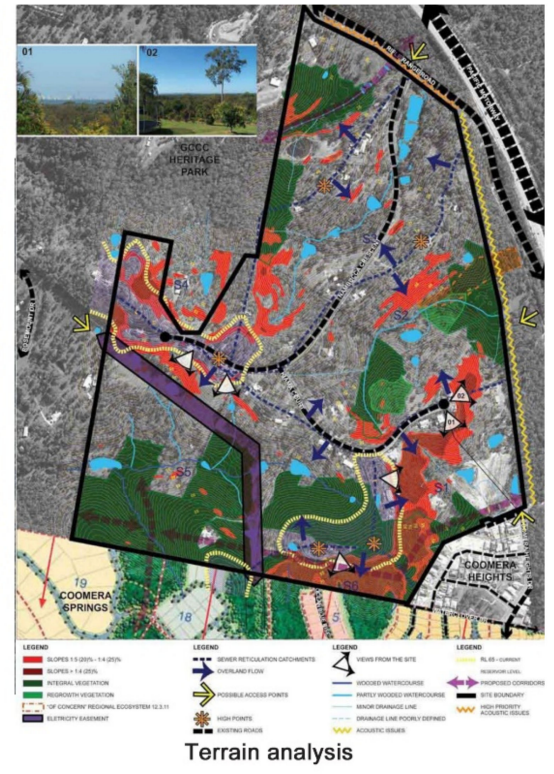

Figure 7. Context analysis of the Coomera town center. 


\subsection{Walkability Evaluation}

Analysis of the distribution map of Coomera's walkability index (Figure 8) showed that the area with highest walkability distribution is located in the northeast, and walkability decreases along the main roads leading to the surroundings, such as Conochie Pi, Howell Cres, Residential cct, and Song cares. The area with lowest walkability distribution is located in the southeast, which is greatly affected by topography. The walkability comfort index and walking color index are good, the walkability convenience index and walkability environment safety index are moderate, and the public transportation convenience index and functional service convenience index need to be improved.

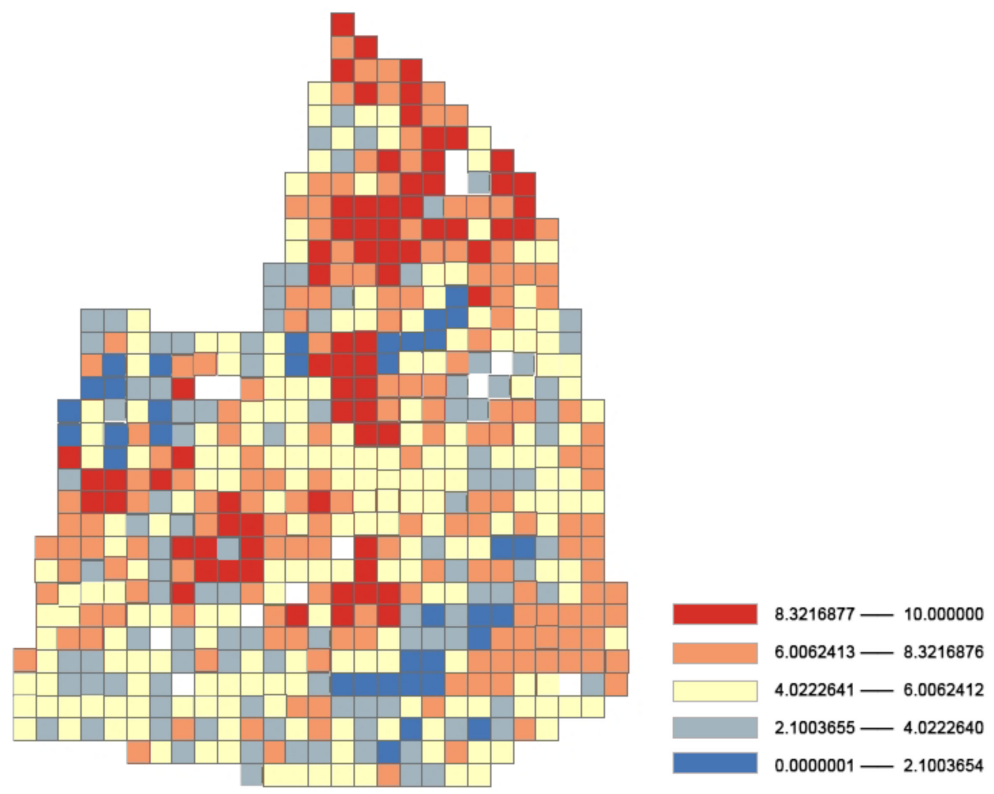

Figure 8. Evaluation result of Coomera walkability.

\subsection{Walkability Design}

\subsubsection{Master Plan}

Based on the environmental analysis and walkability evaluation results, the proposed Walkable Coomera Residential Community seeks to integrate residential, commercial, community, and recreational uses with passive open space areas to create a sustainable and walkable community and living environment. To offer more opportunities for walking and cycling and attract more supporters of walkability, the Master Plan (Figure 9) proposes a complex, interconnected system of streets and ecosystems. The street system incorporates the existing road reserves and allows road connections to the surrounding neighborhoods. Green corridors are introduced to connect regional ecosystems, which can not only give residents a walking experience in the landscape but also protect the patches of regional habitat and waterways. 


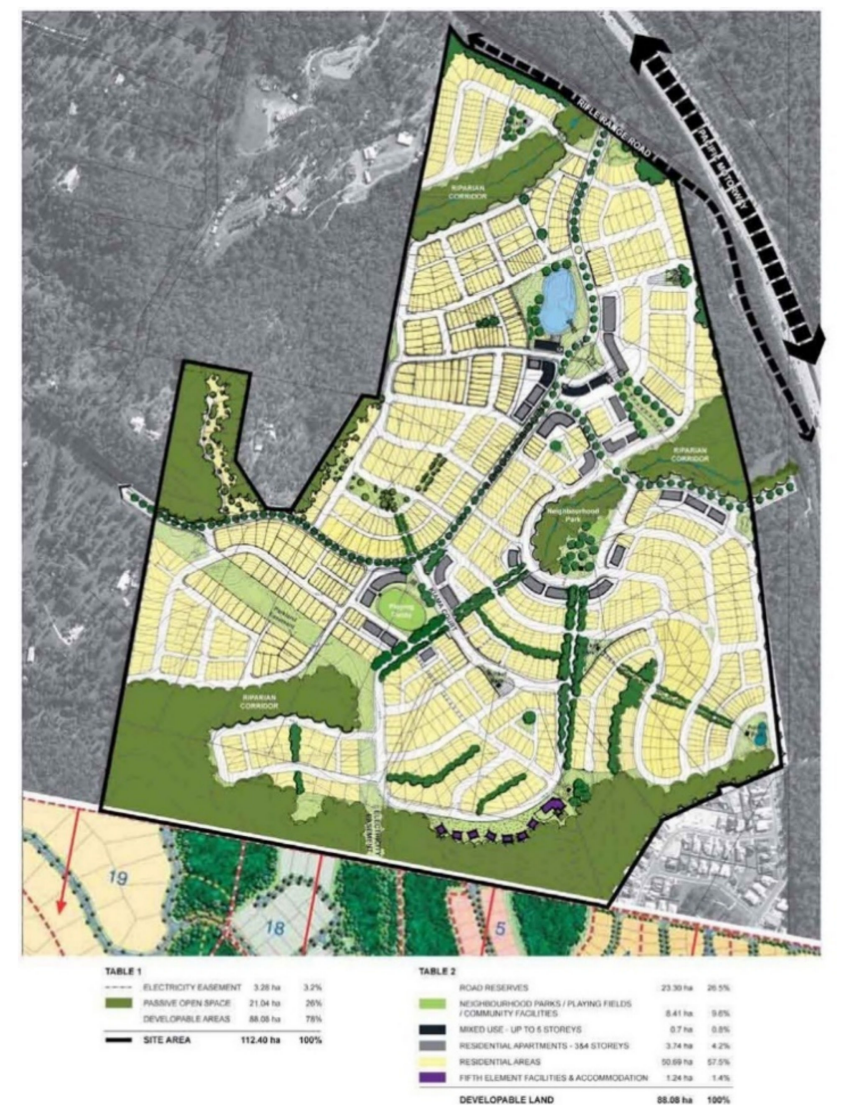

Figure 9. Master plan of the Coomera town center.

\subsubsection{Allotment Types}

To promote a livable and walkable environment with a safe village atmosphere, the earliest stages of development would allow the construction of lower-density residential allotments on land adjacent to Rifle Range Road and Nambucca Crescent. Moreover, implementation at the village center and the highest density node in subsequent stages would occur when rising population numbers make the village a sustainable economic proposition.

As shown in Figure 10, many types of land use have been planned. For example, mixed use, residential apartments (three-to-four stories and three stories), home offices, townhouses, duplexes, courtyards, small lots, and traditional lots coexist. The major recreational node, within a 5-10-min walking distance from most dwellings, adjoins the top of the ridge to neutralize noise issues from the Pacific Motorway. Provision of higher-density residential and mixed-use areas around the village center would facilitate residents' access to mixed-use areas by walking or bicycling and increase the utilization of infrastructure. Bus stops would be established near crossroads of the highest-order roads to maximize exposure of traffic flows within the community and surrounding neighborhoods and to enable residents to utilize various modes of transportation. 


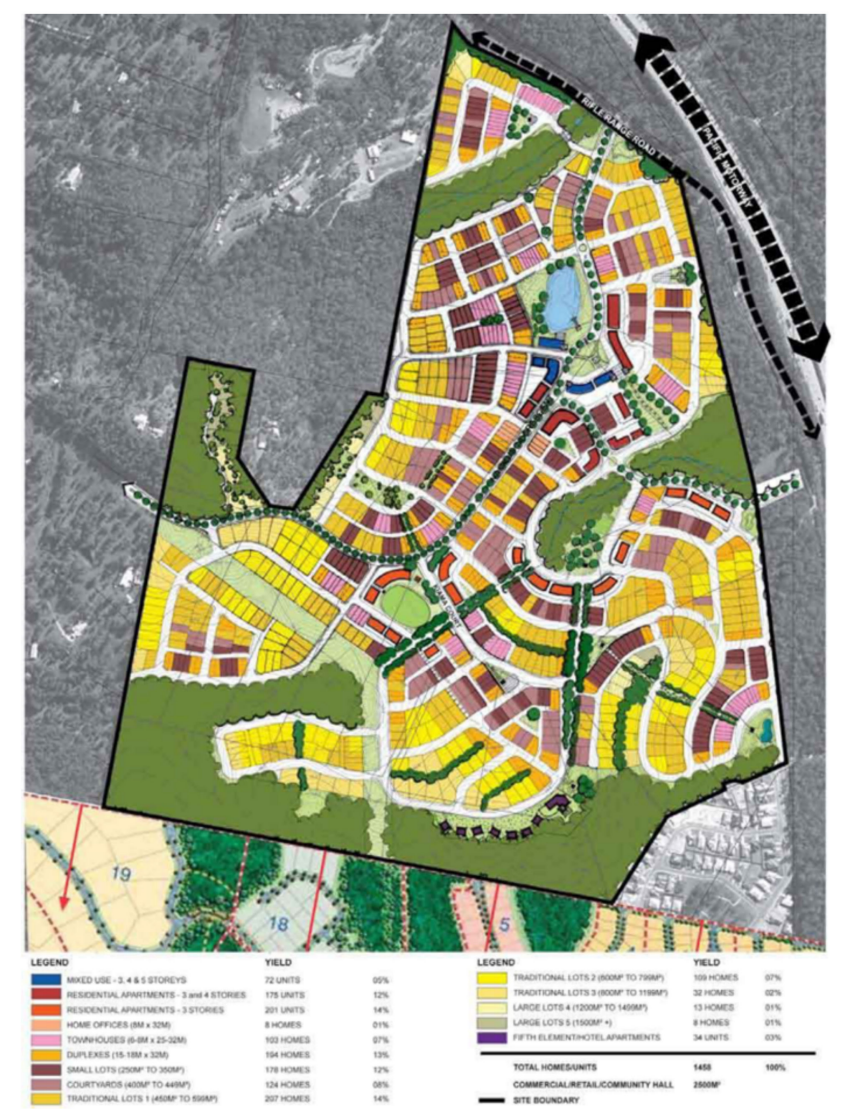

Figure 10. Allotment types of the Coomera town center.

\subsubsection{Density}

Based on the South East Queensland Regional Plan, incorporating higher-density residential uses in public transit-oriented development precincts will increase vitality and provide more convenient access to services and transport for residents. The Master Plan (Figure 11) proposes two density nodes of 33 dwellings per net hectare: one located around the village center/lake park and one around the neighborhood park (purple). The remaining residential areas will achieve a broad density of 25 dwellings per net hectare with some localized pockets of densities adjacent to open space amenities. 


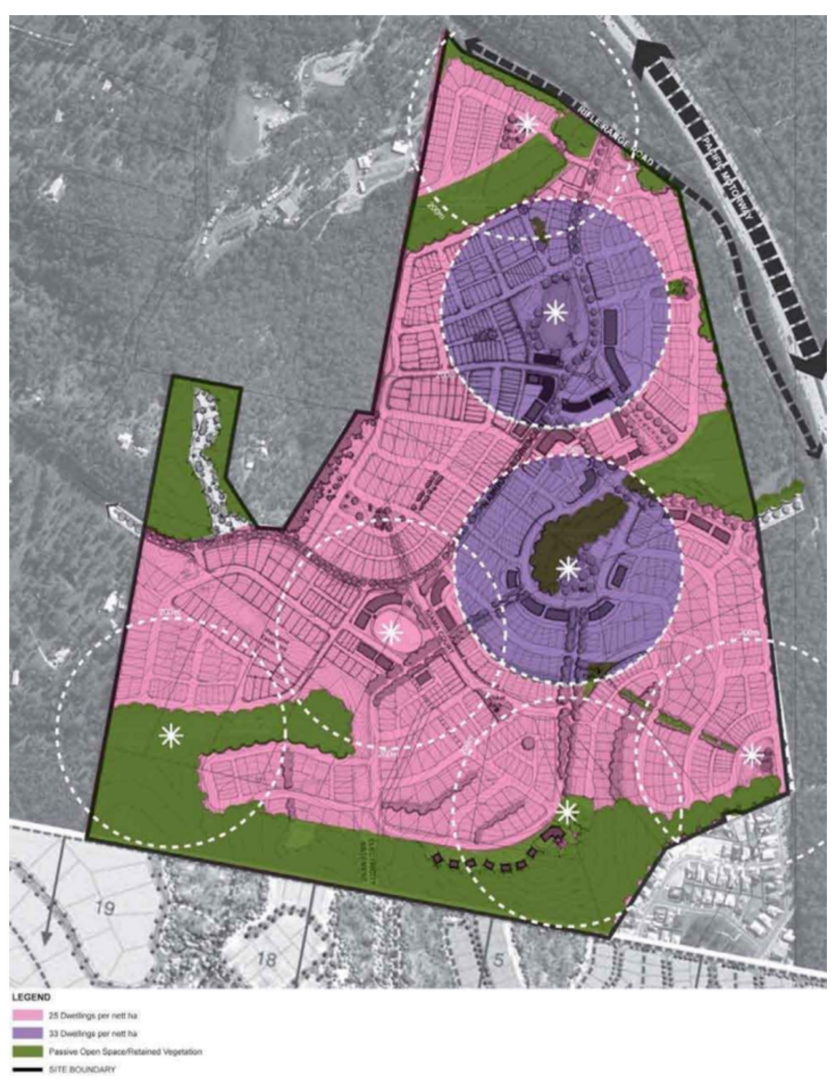

Figure 11. Proposed densities of the Coomera town center.

\subsubsection{Road Network and Public Transport}

Based on the zero-even distribution of traffic and a legible and efficient movement network, a hierarchy of roads has been established that includes boulevards, local streets, lanes, and higher-order collector streets. Rear lanes are provided most effectively to accommodate higher residential densities while preserving high-quality streetscapes free from multiple garages and driveway access points. The proposed Walkable Coomera Residential Community is designed to provide acceptable solutions for walkability.

The Master Plan (Figure 12) shows a major road network that satisfies issues related to safety, amenities, convenience, and economy. Street interconnectivity has been maximized. Potential bus stops should be designed for compliance with the requirement for every proposed dwelling being within $400 \mathrm{~m}$ of a bus route. Apart from the existing road connection from Nambucca Crescent to Rifle Range Road, the Master Plan allows the following road connections to recently completed and future streets: a connection to Coomera Heights Drive in the southeast of the site, a central connection through the Council Parkland to Rifle Range Road, and a connection through the electrical easement through to Rosemount Drive to the west. A local road network reinforces connectivity through multiple connections from all directions to the village center. Further, car parks have been provided in accordance with Council Land Development Guidelines. Streets have good path quality and artistic road environment. 


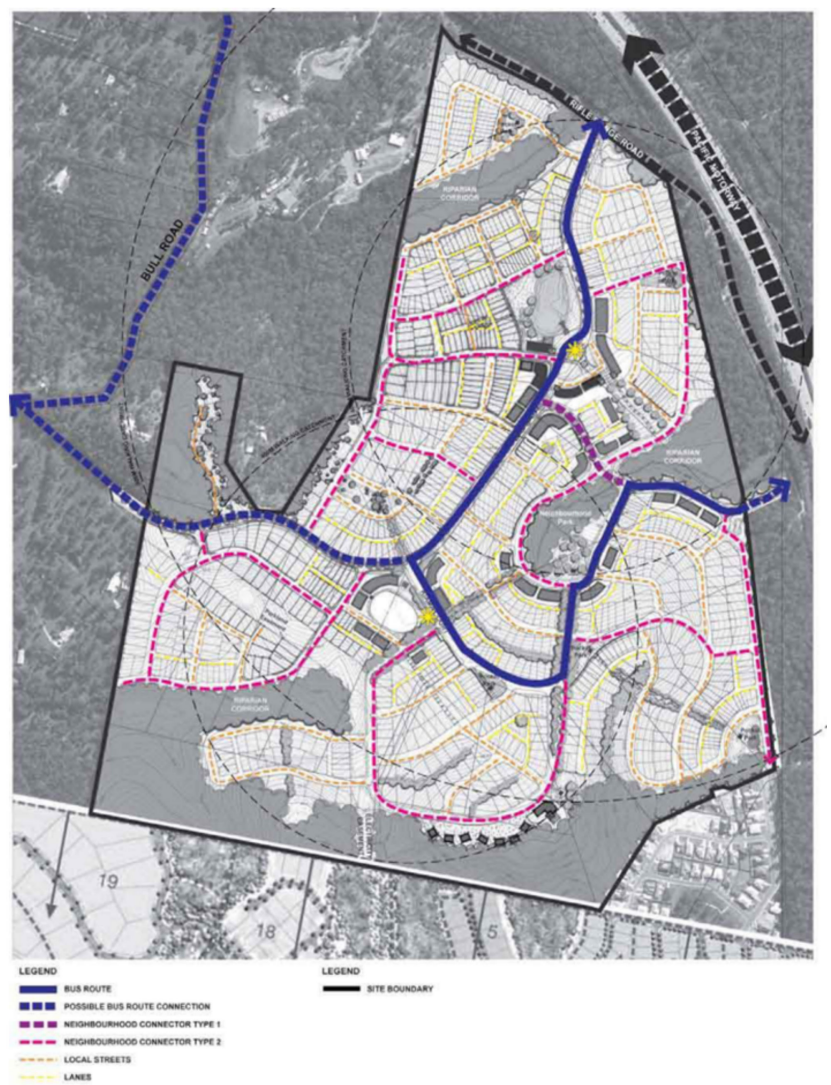

Figure 12. Road and public transport network of the Coomera town center.

From the public transport perspective, the density of development and the mix of uses and accessibility will maximize the use of any future public transport system. Public transport uses shall be provided throughout and adjoining the subject land to connect to the Coomera Town Centre's transit center, providing easily accessible services through the village with bus stops within a 400-m walking distance from any one point. At the same time, the existing Nambucca Crescent will be upgraded to support a future bus route. Possible bus stops may be located in the village center or playing fields, adjacent to the higher-density residential areas.

\subsubsection{Pedestrian and Bicycle Network}

A network of pedestrian paths, walking trails, and cycle ways is an integral part of the open space system. The Master Plan will link the conservation areas, village center, neighborhood parks, playing field, and pocket parks within the development and the adjoining open space systems (Figure 13). As can be seen from the Ability for Walking and Cycling Plan (Figure 14), the network's suitability for walking is high to medium, and cycling areas occupy the main proportion. They are mostly arranged on the main traffic roads, which are not suitable for many in the corner area. 


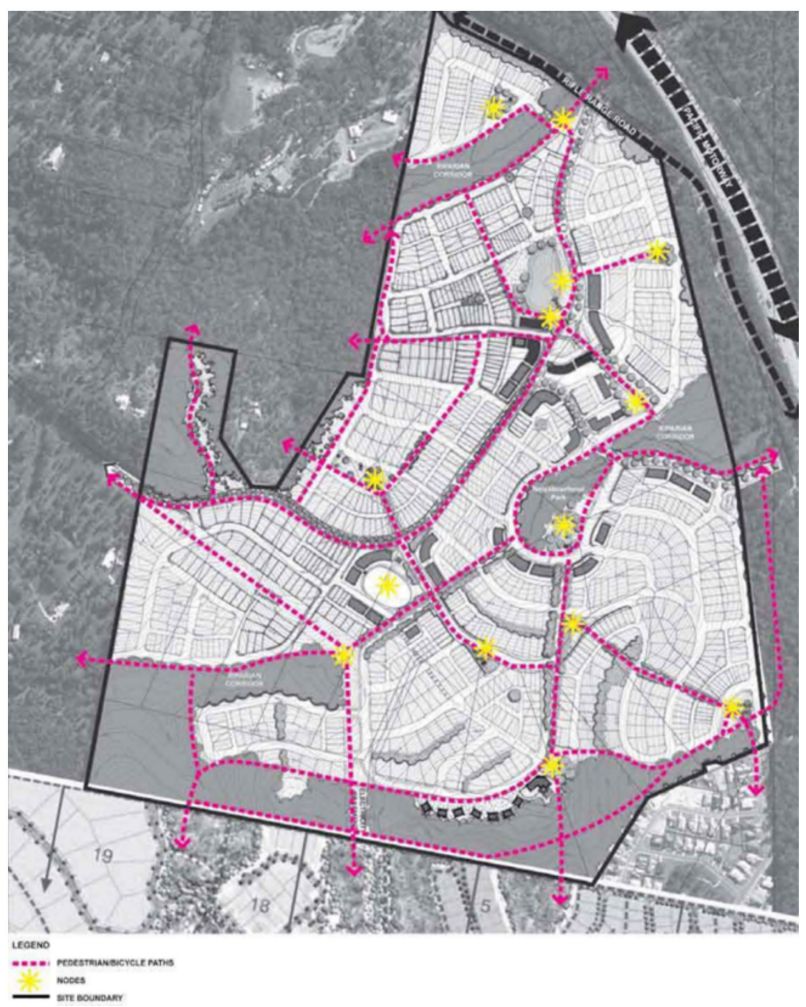

Figure 13. Pedestrian and bicycle network of the Coomera town center.

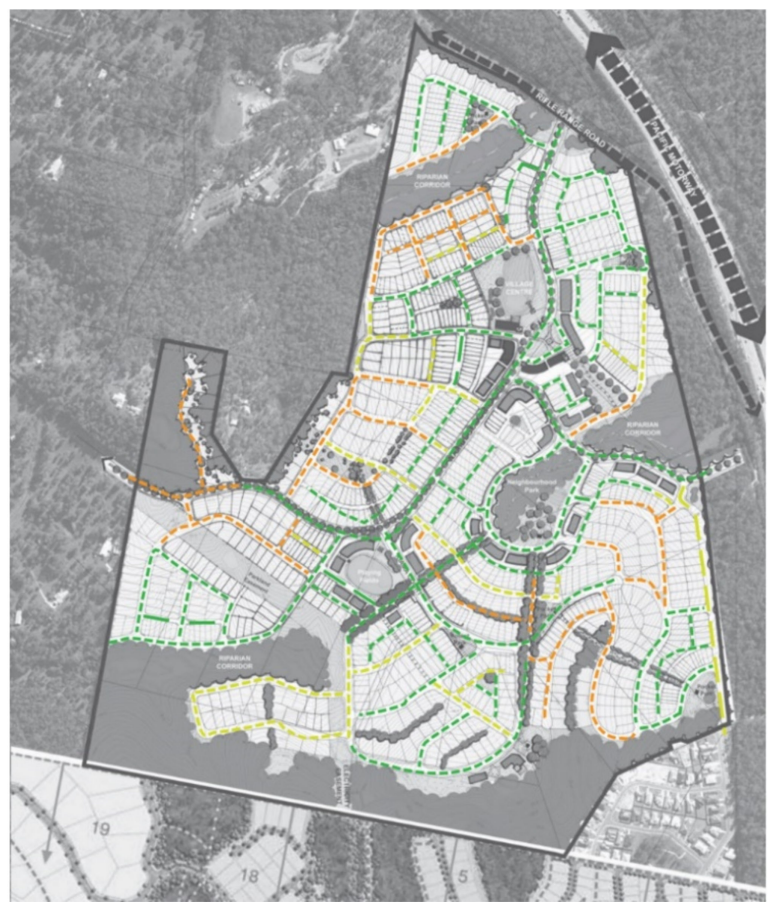

Figure 14. Walkability and ease of cycling in the Coomera town center.

The purpose of the network, including on-street cycle lanes, is to create an integrated and seamless network for pedestrian and cycle paths that provide safe, attractive, and usable connections, and which is also well-signed and easily understandable for users. This will ensure that major cycle ways and pedestrian routes are located in prominent and visually attractive areas to promote their use, and the cycling areas provide real modal alternatives for residents and visitors to the community. Detailed design will 
ensure a well-graded network of pedestrian and cycle ways on sloping land, and multi-use linear pathways running alongside major watercourses and environmental corridors will support walkability.

\subsubsection{Open Space Network and Connectivity}

The public and open spaces are designed to promote a sense of belonging, personal safety, and community identity for residents. Moreover, this design has ecological and catchment protection functions, promoting environmental awareness, and offering opportunities for education, social interaction, recreation, and healthy lifestyles, especially for young people (aged 6-20 years) and families. The open space band through the Walkable Coomera Residential Community includes a central area of urban bushland for passive recreational space, which is integral to the design's form, function, and character. The Master Plan (Figure 15) will integrate parkland with remnant vegetation and watercourses. Moreover, it will create a link to external habitat and adjacent forested areas, such as by framing the residential community with trees. Thus, an urban environment is created that brings together the best in sub-tropical architecture and public space design to make a safe, legible, and permeable link between the residential areas, village center, and recreational nodes. All public spaces will be safe and accessible, promoting personal security and walkability. A series of smaller and more intimate streets with landscaped verges and shady tree canopies will create a pleasant and friendly environment for pedestrians and cyclists. These will form a well-connected street system.

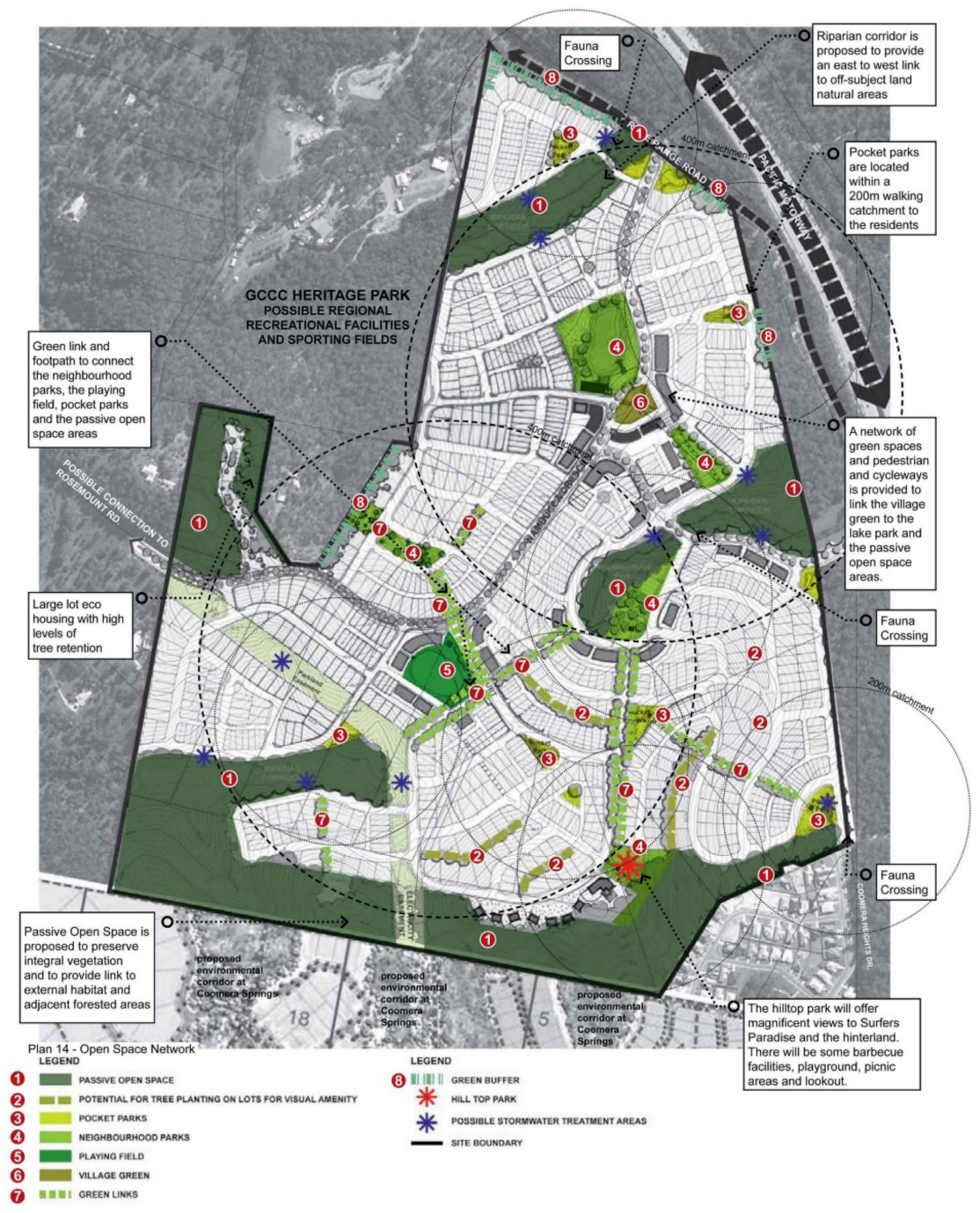

Figure 15. Open space network of the Coomera town center. 


\subsubsection{Proposed Mixed-Use Centre}

The Master Plan proposes a mixed-use central precinct including some three- to five-story residential apartments above commercial buildings, home offices, community facilities, and a range of attached and detached residential projects, along with a retail component of approximately $2600 \mathrm{~m}^{2}$. The mixed-use center and the village green will be a hub of the community and offer vibrant street-front activities.

The mixed-use center (Figure 16) is north oriented to capture views of the lake and passive open spaces to the north and south. It is centrally located at the site and within a $400-800 \mathrm{~m}$ walking distance to the dwellings to provide opportunities for residents to walk or cycle to the park and commercial areas.
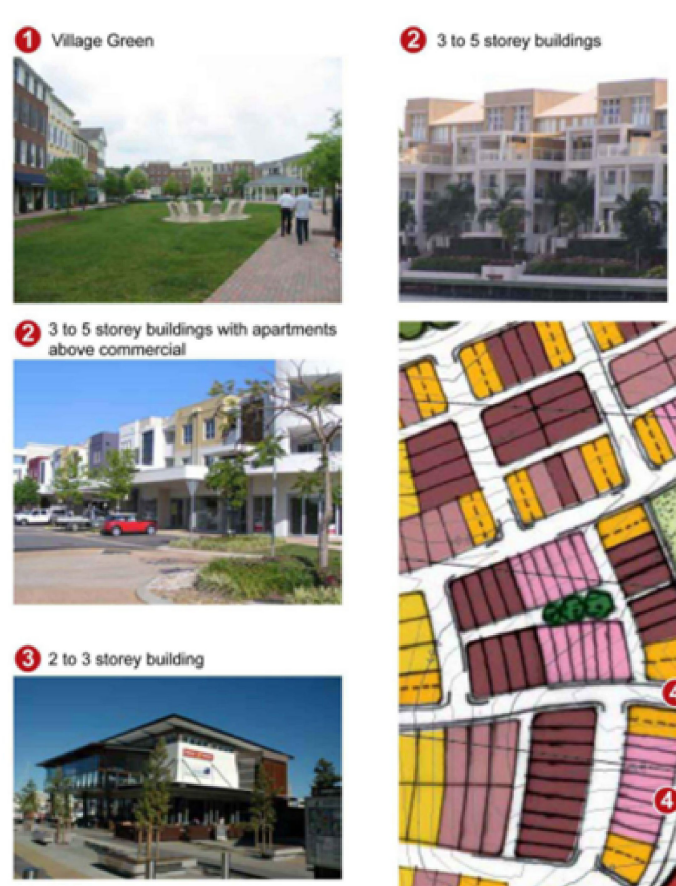

2 to 5 storey buildings with
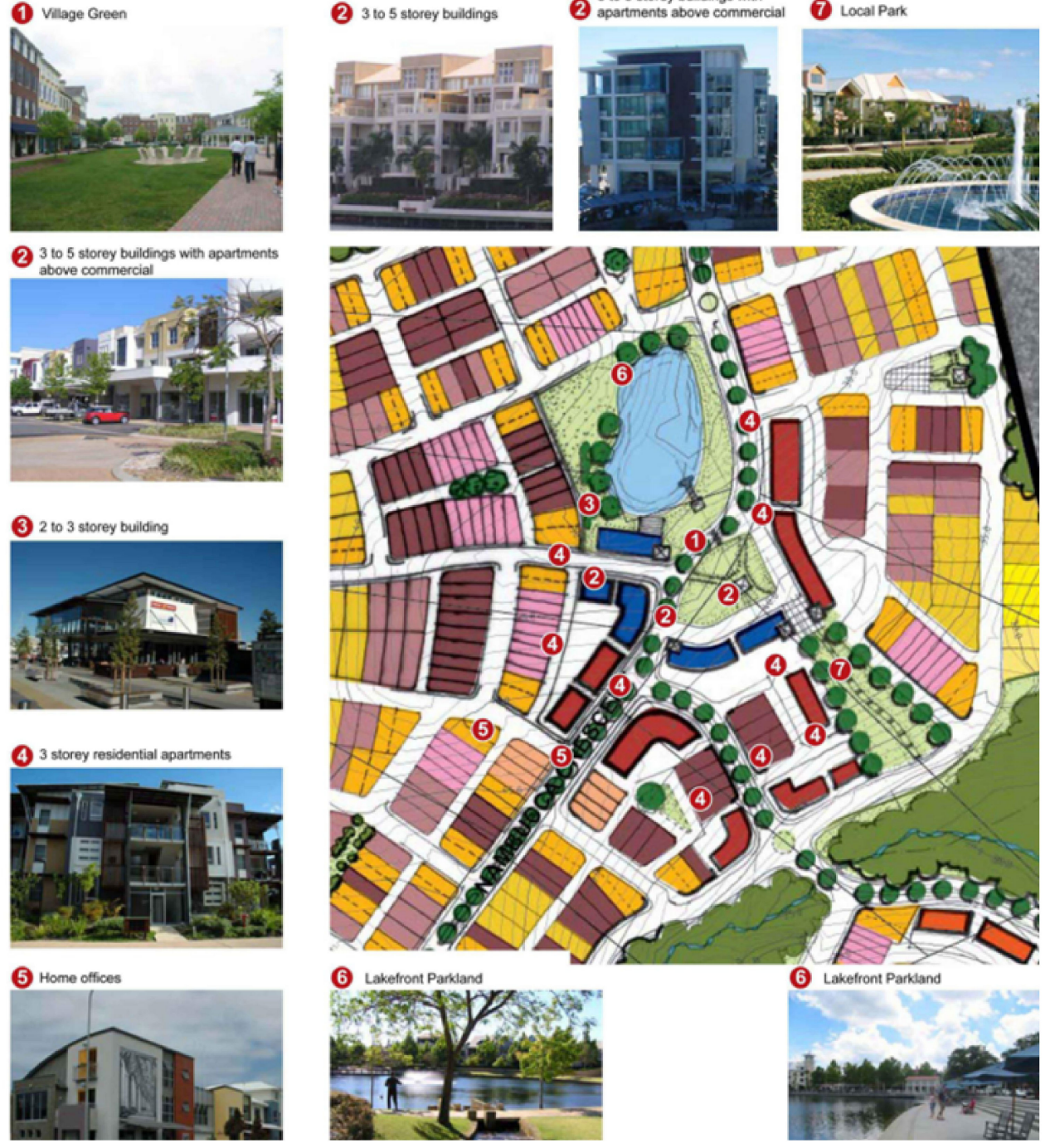

Figure 16. Mixed-use center of the Coomera town center.

\subsubsection{Detailed Street Design for Walkability}

As many streets vary in width and edge treatments, each street will need to be reviewed and redesigned in detail on a case-by-case basis. The successful integration of built forms with lively and pedestrian-friendly streets will facilitate high levels of community interaction; simultaneously, high-quality landscaped streets will be designed for ensuring safety and walkability and for creating a successful accommodating space for diverse users, including solitary walkers, families with strollers, commuter cyclists, and 
everyday traffic. Thus, street space integration and its coordination with the surrounding environment will be ensured.

To enrich the people's lifestyle and provide a space for casual meetings and interaction opportunities within a comfortable and safe environment, the Master Plan divides the streets into three types: main streets, local streets, and rear lanes. Moreover, the Master Plan considers different design responses depending on the nature of the streets through many street-capping components including lush landscapes, integrated streets, outdoor furniture, adequate signage and road finding, good lighting, adaptable structures, suitable materials, and diverse public art.

\section{Conclusions}

It is undeniable that walking is a significant component of future urban transport systems and that urban walkability plays a critical role in urban sustainability $[10,19]$. A city's sub-center walkability system comprises a public transportation system and a pedestrian community system. The introduction of urban walkability in the infancy of the construction of urban sub-centers not only circumvents the established development problems of city centers but also ensures a virtuous cycle of city center and urban subcenter development. Ultimately, all efforts to promote walking aim to create walkable communities. A walkable community is carefully designed to integrate the pedestrian system into the community structure.

Based on key urban design and development pre-documents, this study verifies and explores the applicability of urban walkability theory and methodology in real places. Moreover, it delineates the walkability framework and methodology in the urban subcenter setting. However, different urban backgrounds and policies can have a significant effect on the degree of urban walkability design and the design methods.

Therefore, there are many issues that still require further exploration in future research. First, beginning with different urban backgrounds, the relationship between the proportion of people who use private and public transportation and walkability design should be compared. Moreover, future studies should consider increasing the proportion of people who use private vehicle transportation as an index for determining the feasibility of the walkability index. Second, by combining case studies, a comparative study on walkability that includes urban sub-centers that have a high proportion of private and public transportation should be conducted. Further, future research should focus on the scope of the application and quantification of an urban sub-center's pedestrian framework. By introducing a walking framework, studies should compare and analyze the differences between urban sub-centers of different geographical types and specialized functions to verify whether this scope applies to all urban sub-centers' pedestrian design systems. Moreover, with respect to walkability evaluation standards, studies should screen several wide-ranging, international standards for pedestrian evaluation, such as from the perspective of transit-oriented or private vehicle-oriented development standards. Studies should extract data of individual cases under the framework's guidance and compare the key points' scales and weights using fuzzy assessment to optimize the framework and method. With respect to the evaluation method, a set of data-based and scientific urban sub-center pedestrian frameworks should be developed through the mining and analysis of large amounts of data to guide the construction of the urban sub-center pedestrian system.

Author Contributions: Conceptualization, J.S. and M.Y.; methodology, J.S. and M.Y.; software, M.Y.; validation, Y.T. and M.Y.; formal analysis, M.Y. and G.L.; investigation, Y.Z.; resources, Y.L. and Q.S.; data curation, D.L.; writing—original draft preparation, J.S. and M.Y.; writing—review and editing, J.S. and M.Y.; visualization, Y.L.; supervision, J.S.; project administration, J.S. and M.Y.; funding acquisition, J.S. All authors have read and agreed to the published version of the manuscript.

Funding: This research was funded by the National Natural Science Foundation of China (51878339); The Fundamental Research Funds for the Central Universities (105-11042010016); Key Project of Philosophy and Social Science Research in Colleges and Universities in Jiangsu Province (2019SJZDA020); Project of the Social Science Fund of Jiangsu Province (19GLB006); Technology Research; Develop- 
ment Program of the Construction Department of Jiangsu Provincial (2018ZD303); and Project of Teaching Studio of Huazhong Agricultural University.

Conflicts of Interest: The authors declare no conflict of interest.

\section{References}

1. Mcmillen, D.P.; Smith, S.C. The Number of Subcenters in Large Urban Areas. J. Urban Econ. 2003, 53, 321-338. [CrossRef]

2. Newman, P.; Jennings, I. Cities as Sustainable Ecosystems: Principles and Practices; Island Press: Washington, DC, USA, 2012.

3. O'Riordan, T.; Voisey, H. The Transition to Sustainability: The Politics of Agenda 21 in Europe; Taylor \& Francis: Abingdon, UK, 2013.

4. Odland, J. The Conditions for Multi-Center Cities. Econ. Geogr. 1978, 54, 234-244. [CrossRef]

5. Passerini, G.; Rodriguez, G.; Ricci, S. Coastal Cities and Their Sustainable Future III; WIT Press: Southampton, UK, 2019.

6. South East Queensland Government. South East Queensland Regional Plan 2009-2031; Minister for Infrastructure and Planning: Brisbane, QLD, Australia, 2009.

7. Gympie Regional Council. Part 3-Strategic Framework; Gympie Regional Council: Burnett, Australia, 2019.

8. The Housing Corporation; English Partnerships; Roger Evans Associates; Llewelyn-Davies. Urban Design Compendium: LlewelynDavies, 2nd ed.; Llewelyn-Davies: London, UK, 2007; Volume 2, pp. 54-72.

9. U.S. Federal Transit Administration; Transit Cooperative Research Program; Transportation Research Board of the National Academies. Transit-Oriented Development in the United States: Experiences, Challenges, and Prospects; Transportation Research Board: Washington, DC, USA, 2004; Volume 102, pp. 425-430.

10. Newman, P.; Kenworthy, J. Urban design to reduce automobile dependence. Opolis 2006, 2, 35-52.

11. Singh, R. Factors Affecting Walkability of Neighborhoods. Procedia Soc. Behav. Sci. 2016, 216, 643-654. [CrossRef]

12. Ben-Joseph, E. Changing the residential street scene: Adapting the shared street (woonerf) concept to the suburban environment. J. Am. Plan. Assoc. 1995, 61, 504-515. [CrossRef]

13. Buchanan, C. Traffic in Towns: A Study of the Long Term Problems of Traffic in Urban Areas; Routledge: London, UK, 2015.

14. Speck, J. Walkable City: How Downtown Can Save America, One Step at a Time. Pedestrians 2012, $103,120$.

15. Yuen, B.; Chor, C.H. Pedestrian streets in Singapore. Transportation 1998, 25, 225-242. [CrossRef]

16. Marvin, S.; Yang, J.; Zheng, Y.; Rutherford, J. Correlation, Mechanism, Control: Research on High-density Urban Pedestrian Suitability Environment Construction Based on Micro-climate Assessment. Urban Plan. Int. 2019, 34, 16-26. [CrossRef]

17. O'Hare, D. Urban Walkability in the Subtropical City: Some Intemperate Considerations from SEQ. In Subtropical Cities 2006 Conference Proceedings: Achieving Ecologically Sustainable Urbanism in a Subtropical Built Environment; Queensland University of Technology: Brisbane, Australia, 2006.

18. Britain Government. Chapter Xli: Stationery Office. In Birmingham City Council Act 1985: Elizabeth II; Britain Government: London, UK, 1985.

19. Kenworthy, J. Urban planning and transport paradigm shifts for cities of the post-petroleum age. J. Urban Technol. 2007, 14, 47-70. [CrossRef]

20. Cook, S.; Tjandraatmadja, G.; Ho, A.; Sharma, A. Definition of Decentralised Systems in the South East Queensland Context; Urban Water Security Research Alliance: Brisbane, Australia, 2008.

21. Ivory, V.C.; Blakely, T.; Pearce, J.; Witten, K.; Bagheri, N.; Badland, H.; Schofield, G. Could strength of exposure to the residential neighbourhood modify associations between walkability and physical activity? Soc. Sci. Med. 2015, 147, 232-241. [CrossRef]

22. Marshall, W.E.; Piatkowski, D.P.; Garrick, N.W. Community design, street networks, and public health. J. Transp. Health 2014, 1, 326-340. [CrossRef]

23. Etemadi, A.; Abnet, C.C.; Kamangar, F.; Islami, F.; Khademi, H.; Pourshams, A.; Dawsey, S.M. Impact of body size and physical activity during adolescence and adult life on overall and cause-specific mortality in a large cohort study from Iran. Eur. J. Epidemiol. 2014, 29, 95-109. [CrossRef]

24. Bahrainy, H.; Khosravi, H. The impact of urban design features and qualities on walkability and health in under-construction environments: The case of Hashtgerd New Town in Iran. Cities 2013, 31, 17-28. [CrossRef]

25. Zhang, Y.; Wu, W.; Lin, S.; Zhang, S. Study on the Aging of Outdoor Living Space in Urban Residential Areas-Taking Hangzhou as an Example. Archit. Cult. 2019, 7, 124-125.

26. Gargiulo, C.; Zucaro, F.; Gaglione, F. A set of variables for elderly accessibility in urban areas. TeMA J. Land Use Mobil. Environ. 2018, 53-66. [CrossRef]

27. Bian, Y.; Zhu, W. Walkability of Child Space: Learning from UNICEF Child-Responsive Urban Planning Handbook. Urban Design 2019, 3, 70-79.

28. Yates, M.T.; Balmforth, D.; Lopez-Marco, A.; Uppal, R.; Oo, A.Y. Outcomes of patients diagnosed with COVID-19 in the early postoperative period following cardiac surgery. Interactive Cardiovasc. Thorac. Surg. 2020, 31, 483-485. [CrossRef]

29. Algeciras, J.A.R.; Consuegra, L.G.; Matzarakis, A. Spatial-temporal study on the effects of urban street configurations on human thermal comfort in the world heritage city of Camagüey-Cuba. Build. Environ. 2016, 101, 85-101. [CrossRef]

30. Huang, M.; Liu, G.; Tao, Y. Walk Score Calculation of Taipingqiao Street in Beijing; Beijing Surveying and Mapping: Beijing, China, 2017.

31. Yang, J.; Wu, H.; Zheng, Y. Research on Characteristics and Interactive Mechanism of Street Walkability through Multi-Source Big Data: Nanjing Central District as a Case Study. Urban Plan. Int. 2019, 34, 33-42. [CrossRef] 
32. Zhang, H.; Jiang, Y.; Tao, C.; Wang, B.; Xia, H.; Pang, B. Walkability evaluation of daily service facilities based on low-carbon travel guide. Sichuan Build. Sci. 2016, 42, 97-101.

33. Zhang, Y.; Jun, L.I. Spatial Pattern of Urban Streets Based on Low-Carbon Travel. Mod. Urban Res. 2016, 4, 60-67.

34. Wu, S. Research on the Block Scale and Density of Road Network Planning Under the Guidance of Low-Carbon. Huazhong Archit. 2016, 7, 29-33.

35. Abley, S.; Turner, S.; Agency, N.T. Predicting Walkability; NZ Transport Agency: Wellington, New Zealand, 2011.

36. Blecic, I.; Cecchini, A.; Trunfio, G.A. Towards a Design Support System for Urban Walkability. Procedia Comput. Sci. 2015, 51, 2157-2167. [CrossRef]

37. De Boer, E. Transport Sociology: Social Aspects of Transport Planning; Elsevier Science: Amsterdam, The Netherlands, 2013.

38. Wang, L. Research on the Urban Rail Transit Design between Urban sub-center and Center of City. J. Railw. Eng. Soc. 2017, 34, 73-76.

39. Reid, S. Fit for purpose: Evaluating walkability. In Proceedings of the Institution of Civil Engineers-Engineering Sustainability; Thomas Telford Ltd.: London, UK, 2008; Volume 161, pp. 105-112. [CrossRef]

40. Shao, Z. New Urban Complex. The New Urban Area Development; Springer: Berlin/Heidelberg, Germany, $2015 ;$ pp. 321-323.

41. Gong, F.-Y.; Zeng, Z.-C.; Zhang, F.; Li, X.; Ng, E.; Norford, L.K. Mapping sky, tree, and building view factors of street canyons in a high-density urban environment. Build. Environ. 2018, 134, 155-167. [CrossRef]

42. Liang, C.; Zeng, J. Research on Optimization of Walking Environment in Historical District Based on Importance-performance Analysis: A Case Study of the Five Avenues, Tianjin. 2019. Available online: https://www.researchgate.net/publication/33 7020067_Research_on_Optimization_of_Walking_Environment_in_Historical_District_Based_on_Importance-performance_ Analysis_A_Case_Study_of_the_Five_Avenues_Tianjin (accessed on 20 February 2021).

43. Liu, M.; Jiang, Y.; He, J. Quantitative Evaluation on Street Vitality: A Case Study of Zhoujiadu Community in Shanghai. Sustainability 2021, 13, 3027. [CrossRef]

44. Wang, H.; Yang, Y. Neighbourhood walkability: A review and bibliometric analysis. Cities 2019, 93, 43-61. [CrossRef]

45. Yin, R.K. Estudo de Caso: Planejamento e Métodos; Bookman: Taipei, China, 2001.

46. Zlatkovic, M.; Zlatkovic, S.; Sullivan, T.; Bjornstad, J.; Shahandashti, S.K.F. Assessment of effects of street connectivity on traffic performance and sustainability within communities and neighborhoods through traffic simulation. Sustain. Cities Soc. 2019, 46, 101409. [CrossRef]

47. TTM Consulting Pty. Ltd. (Firm); Gold Coast City Council. Coomera Charrette Planning Study 1995 Report: Draft; TTM Consulting: Brisbane, QLD, Australia, 1995.

48. Frey, H. Designing the City: Towards a More Sustainable Urban Form; Taylor \& Francis: Abingdon, UK, 2003.

49. Wisconsin Department of Transportation; Division of Investment Management; Bureau of Planning. Wisconsin State Highway Plan; Technical Report; Division of Investment Management; Wisconsin Department of Transportation: Madison, WI, USA; Bureau of Planning: Portland, OR, USA, 2000.

50. Griffith, D.A. Modelling urban population density in a multi-centered city. J. Urban Econ. 1981, 9, 298-310. [CrossRef]

51. O'Hare, D. Inner-Urban Sustainability: A Case Study of South Brisbane Peninsula. In Proceedings of the CIB 2003 Int'l Conference on Smart and Sustainable Built Environment, Queensland University of Technology, Brisbane, QLD, Australia, 19-21 November 2003; pp. 1-8.

52. Ennis, G.M.; Finlayson, M.P.; Speering, G. Expecting a boomtown? Exploring potential housing-related impacts of large scale resource developments in Darwin. Hum. Geogr. 2013, 7, 33-42. [CrossRef]

53. Garcia-López, M.-À.; Hémet, C.; Viladecans-Marsal, E. Next train to the polycentric city: The effect of railroads on subcenter formation. Reg. Sci. Urban Econ. 2017, 67, 50-63. [CrossRef]

54. Setiyowati, T.R.; Handayani, W.; Damayanti, M.; Rudiarto, I. Towards an independent city: The role of Ungaran City as a urban sub-center of Semarang City. In IOP Conference Series: Earth and Environmental Science; IOP: Bristol, UK, 2018.

55. Romanos, M.C. Household location in a linear multi-center metropolitan area. Reg. Sci. Urban Econ. 1977, 7, 233-250. [CrossRef]

56. Sargeant, B.; Mitchell, N.; Webb, N. Place Making in the Urban Corridor; Modern Urban Research: Melbourne, VIC, Australia, 2009.

57. Brooke, W.; Minnery, J. Understanding city fringe gentrification: The role of a'potential investment gap'. In Proceedings of the Conference on State of Australian Cities, Griffith University, Brisbane, QLD, Australia, 30 November-2 December 2005; Volume 30.

58. Hillsdon, M.; Panter, J.; Foster, C.; Jones, A. The relationship between access and quality of urban green space with population physical activity. Public Health 2006, 120, 1127-1132. [CrossRef]

59. Iglesias, F.; Shinji, I. Creation and evolution of the open space in the sub center high raise zone of Nishi Shinjuku (Japan). J. Agric. Sci. 2002, 46, 250-264. 